\title{
Powiat kcyński w drugiej połowie XVI w.
}

\section{Marta Piber-Zbieranowska}

Niniejszy artykuł stanowi podsumowanie prac nad opracowaniem mapy powiatu kcyńskiego w 2. poł. XVI w. prowadzonych w Zakładzie Atlasu Historycznego Polski IH PAN w Warszawie w ramach projektu obejmującego stworzenie mapy całej Wielkopolski (województw poznańskiego i kaliskiego) we wspomnianym okresie.

Wedle założeń przyjętych dla całej serii „Atlasu historycznego Polski”" rekonstruowany jest stan osadnictwa oraz państwowe i kościelne podziały administracyjne na $1600 \mathrm{r}$. Podstawę opracowania stanowią tzw. rejestry poborowe z 2. poł. XVI w. uzupełniane danymi z wizytacji kościelnych i lustracji dóbr królewskich, a pomocniczo także z wcześniejszych źródeł - w przypadku Wielkopolski przede wszystkim z ksiąg uposażeń biskupstw gnieźnieńskiego i poznańskiego oraz inwentarzy dóbr kościelnych ${ }^{2}$. Dane z ksiąg sądowych

\footnotetext{
1 W serii „Atlas historyczny Polski. Mapy szczegółowe XVI wieku” [dalej: AHP] dotychczas ukazały się tomy: 3: Województwo lubelskie w drugiej połowie XVI wieku, oprac. S. Wojciechowski, Warszawa 1966 (dostępny w Bibliotece Cyfrowej UMCS: http://dlibra.umcs.lublin.pl/ dlibra/docmetadata?id=947, dostęp: 12 lipca 2015); 7: Mazowsze w drugiej potowie XVI wieku, oprac. W. Pałucki i in., Warszawa 1973

2: Województwo sandomierskie $w$ drugiej połowie XVI wieku, oprac. W. Pałucki i in., Warszawa 1993; 5: Województwo sieradzkie i województwo łęczyckie w drugiej połowie XVI wieku, oprac. H. Rutkowsk i in., Warszawa 1998; 1: Województwo krakowskie w drugiej połowie XVI wieku, oprac. H. Rutkowski i in., Warszawa 2008. Kolejne tomy AHP (od poświęconego Mazowszu) dostepne są w Repozytorium Cyfrowym Instytutów Naukowych (http://rcin.org.pl/ihpan/dlibra/publication?id=6733\&tab=3, dostęp: 12 lipca 2015). Mapa ujmująca całość dotychczas opracowanych w serii AHP ziem koronnych (wraz z indeksem miejscowości) dostępna jest online (http://atlasfontium.pl/ index.php?article = corona, dostęp: 12 lipca 2015).

2 Jana Łaskiego [...] Liber beneficiorum archidiecezyi gnieźnieńskiej [dalej: LBG], wyd. J. Łukowski [z] uwagami J. Korytkowskiego, t. 1-2, Gniezno 1880-1881; Księga uposażenia diecezji poznańskiej z roku 1510 [dalej: LBP], wyd. J. Nowacki, Poznań 1950; Wizytacje dóbr arcybiskupstwa gnieźnieńskiego i kapituły gnieźnieńskiej z XVI w., wyd B. Ulanowski, Kraków 1920.

3 Kartoteka obejmująca wypisy źródłowe dla miejscowości województw kaliskiego i poznańskiego jest gromadzona i przechowywana w Pracown Słownika Historyczno-Geograficznego Wielkopolski IH PAN w Poznaniu.

4 Teki Dworzaczka. Materiały historyczno-genealogiczne do dziejów szlachty wielkopolskiej XV-XX wieku, PAN i Biblioteka Kórnicka
}

wykorzystane zostały jedynie uzupełniająco w przypadkach wątpliwych, za pośrednictwem wypisów znajdujących się w kartotece „Słownika historyczno-geograficznego Wielkopolski w średniowieczu"3 oraz regestów zgromadzonych w tzw. "Tekach Dworzaczka”4.

Rejestry poborowe to wykazy wpłat podatku nadzwyczajnego na cele wojskowe, który uchwalany był doraźnie przez Sejm Rzeczypospolitej od poł. XV w., jednak dopiero w 2. poł. XVI w. nabrał charakteru powszechnego, obejmując wszystkie kategorie ludności oraz urządzenia przemysłowe funkcjonujące na terenach wiejskich i w miastach ${ }^{5}$. Spisy prowadzono według podziału administracyjnego na województwa i powiaty, a wewnątrz nich na parafie. Poborca odnotowywał nazwę miejscowości oraz podstawę ściąganych płatności liczbę opodatkowanych łanów, zagrodników, komorników, informację na temat istniejących

Kórnik-Poznań 2004 (edycja elektroniczna: http://teki.bkpan.poznan. pl/index_glowna.html, dostęp: 11 lipca 2015). W tekście niniejszego artykułu, cytując odpowiednie regesty z Tek, podano dawne sygnatury stosowane przez Włodzimierza Dworzaczka. W toku dalszych badań nad osadnictwem powiatu kcyńskiego w dobie nowożytnej jako postulat badawczy (do celów weryfikacyjnych danych uzyskanych z rejestrów poborowych) można wskazać konieczność wykorzystania inwentarzy poszczególnych dóbr, które zachowały się w formie wpisów w księgach ziemskich i grodzkich z terenu Wielkopolski. Dla powiatu kcyńskiego zestawiła je Regina Piechota: Katalog inwentarzy dóbr ziemskich XVI-XVIII wieku sporządzony na podstawie ksiąg grodzkich i ziemskich, oprac. H. Karczowa, W. Maciejewska, R. Piechota, Warszawa 1959, s. 296-304. Z interesującego nas okresu pochodzą jednak tylko dwa inwentarze - Gąbina (parafia Chomiąża, 1594 r.) oraz Słupów (parafia własna, 1600 r.). Znakomita większość inwentarzy dotyczy natomiast 2. poł. XVII i XVIII w. Tamże, s. 298, 302.

5 Ogólną charakterystykę rejestrów poborowych wraz z literaturą przedmiotu podaje Irena Gieysztorowa: I. Gieysztorowa, Źródła pisane, w: AHP: Mazowsze, cz. 2: Komentarz, indeksy, s. 17-18. Zob. także K. Boroda, Kmieć, tan czy profit? Co było podstawą poboru łanowego w XV i XVI w.?, w: Człowiek wobec miar i czasu w przeszłości, red. P. Guzowski, M. Liedke, Kraków 2007, s. 152-167; A. Filipczak-Kocur, Skarbowość Rzeczypospolitej 1587-1648, Warszawa 2006, s. 47-53. Na temat rejestrów poborowych województwa kaliskiego zob. K. Chłapowski, Rejestry poborowe województwa kaliskiego z XVI wieku. Wstęp źródłoznawczy, w: Atlas historyczny Polski. Rejestry poborowe województwa kaliskiego wXVI w. red. M. Słoń (http://atlasfontium.pl/, dostęp: 11 lipca 2015). 
tam młynów (ich rodzaj i liczbę kół), wiatraków, kuźni i foluszy oraz karczem. Poborca odnotowywał też zazwyczaj imię i nazwisko właściciela lub dzierżawcy osady bądź czasem zamiast tego jedynie pełniony przezeń urząd lub sprawowaną godność. Rejestry poborowe dla powiatu kcyńskiego rzadko notują jednak właścicieli bądź dzierżawców, czyniąc to tylko w przypadku, gdy dana miejscowość podzielona była na dwa lub więcej działy własnościowe - takich miejscowości jest jednak stosunkowo niewiele. Osobno spisane są posiadłości klasztoru w Wągrowcu. Analizując bogactwo informacji dostarczanych przez rejestry poborowe, trzeba jednak zachować dużą ostrożność i pamiętać o ich mankamentach. W rejestrach nie odnotowywano bowiem osiedli czasowo zwolnionych z podatku: nowo założonych bądź dotkniętych różnego rodzaju klęskami żywiołowymi (np. spalonych) ani też - co szczególnie ważne - folwarków szlacheckich, które były na stałe zwolnione z podatku. W rejestrach brak także często osiedli, z których podatek płacono łącznie z inną osadą - przysiółków, osad młyńskich, kuźniczych oraz karczem z własną nazwą leżących poza wsią, a także przedmieść należących do miasta. Wiadomo też, że czasem podawano poborcy zaniżoną liczbę łanów bądź też łany uprawiane deklarowano jako puste, gdyż podatek od nich był o $1 / 3$ niższy $^{6}$. Z 2. poł. XVI w. dla powiatu kcyńskiego zachowało się

6 K. Górska, Przyczynek do krytyki rejestrów poborowych z XVI wieku, „Studia Źródłoznawcze", 1, 1957, s. 185-189; I. Gieysztorowa, Źródła i szacunki do osadnictwa i demografii Polski XVI i XVII w. , ,Kwartalnik Historii Kultury Materialnej", 10 (3-4), 1962, s. 575-593, zwłaszcza s. 576-584; Z. Guldon, Uwagi w sprawie przydatności badawczej rejestrów poborowych z XVI w., ,Zapiski Historyczne”, 31 (1), 1966, s. 73-79. Dla omawianego terenu zagadnienie to omówił ostatnio Paweł Klint: P. Klint, Szlachecki obrót ziemią w powiecie kcyńskim w latach 1626-1655, Wroctaw 2012, s. 25-26.

7 AGAD, Archiwum Skarbu Koronnego: 1564 r. - ASK I 12, k. 568-586; 1565 r. - ASK I 4, k. 216-236; 1576 r. - ASK I 12, k. 654-662; 1577 r. - ASK I 13, k. 193-210v; 1578 r. - ASK I 4, k. 331-353v; 1579 r. - ASK I 4, k. 354-393; 1580 r. - ASK I 4, k. 413-465; 1581 r. - ASKI 4, k. 537-560; 1582 r. - ASK I 4, k. 576-597; 1583 r. - ASK I 4, k. 732-755; 1591 r. - ASK I 4, k. 774-791v. Rejestry z lat 1577 i 1579 zostały opublikowane przez Adolfa Pawińskiego. Polska XVI wieku pod względem geograficzno-statystycznym, t. 1: Wielkopolska, Warszawa 1883 (Żródła Dziejowe [dalej: ŻD], 12), s. 180-195. Edycja ta zawiera jednak wiele błędów w liczbie zatrudnionej ludności oraz opuszczenia, nie odnotowując w ogóle urządzeń technicznych.
11 rejestrów poboru z lat 1564-1591. Przechowywane są one obecnie w Archiwum Głównym Akt Dawnych w Warszawie?.

W omawianym okresie powiat kcyński stanowił administracyjnie część województwa kaliskiego, które obejmowało wówczas oprócz tego pięć powiatów: kaliski, pyzdrski, koniński, gnieźnieński i nakielski. Powiat kcyński znajdował się w północnej części województwa, granicząc od północy z nakielskim, a od południa z gnieźnieńskim. Do 1768 r. stanowił część województwa kaliskiego, kiedy to wydzielono z niego trzy północne powiaty - gnieźnieński, kcyński i nakielski - tworząc województwo gnieźnieńskie.

Powiaty powstały jako okręgi sądowe szlachty ${ }^{8}$. Ich kształtowanie się polegało na stopniowym wyodrębnianiu się $\mathrm{z}$ większych ziem pewnych mniejszych terytoriów koncentrujących się wokół centrów powiatów - ich późniejszych stolic. Proces ustalania się powiatów sądowych w Wielkopolsce przypada na 2. poł. XIV w. W końcu tego stulecia większość z nich jest już uformowana. Poświadczają to zachowane księgi sądowe ziemskie będące owocem pracy kancelarii tych sądów9 Sądy ziemskie nie miały kompetencji w stosunku do dóbr kościelnych i królewskich. Podlegały im jedynie dobra szlacheckie, funkcjonując wedle zasady, że właściwym do rozpatrywania danej sprawy spornej jest sąd tego powiatu, w którym leżą

Wspomniane rejestry (oprócz rejestru z 1580 r.) doczekały się obecnie edycji elektronicznej: http://atlasfontium.pl/, dostęp: 11 lipca 2015, oprac. A. Borek, M. Piber-Zbieranowska. Do celów porównawczych (zob. niżej) korzystano także z wydanego drukiem rejestru z lat 16181620: Rejestr poborowy województwa kaliskiego 1618-1620 [dalej: Rp1618], wyd. A.J. Parczewski, Warszawa 1879 (Analekta Wielkopolskie, 1), s. 238-296.

8 H. Rutkowski, Granice państwowych jednostek terytorialnych, AHP: Województwo krakowskie, cz. 2, s. 27. Prawdopodobną datę powstania powiatu kcyńskiego podaje Andrzej M. Wyrwa. Według niego może być to $1361 \mathrm{r}$ r., kiedy w źródłach po raz pierwszy pojawia się określenie „in districtu Palucensi” (Kodeks dyplomatyczny Wielkopolski, t. 3, Poznań 1877, nr 1453). A.M. Wyrwa, Pałuki - nazwa i terytorium w świetle źródet $\mathrm{i}$ literatury. Stan badań, w: Osadnictwo i architektura w rejonie Łekna we wczesnym średniowieczu, red. A.M. Wyrwa, Poznań 1989 (Studia i Materiały do Dziejów Pałuk, 1), s. 12, 20. Zob. też: Kodeks dyplomatyczny Wielkopolski, t. 3, nr 1522, 1973, 2008; t. 6, nr 285.

9 A. Gąsiorowski, Powiat w Wielkopolsce w XIV-XVI wieku. Z zagadnień zarządu terytorialnego i podziatów Polski późnośredniowiecznej, Poznań 1965, s. 24-27.

\section{Studia Geohistorica • Nr 03. 2015}




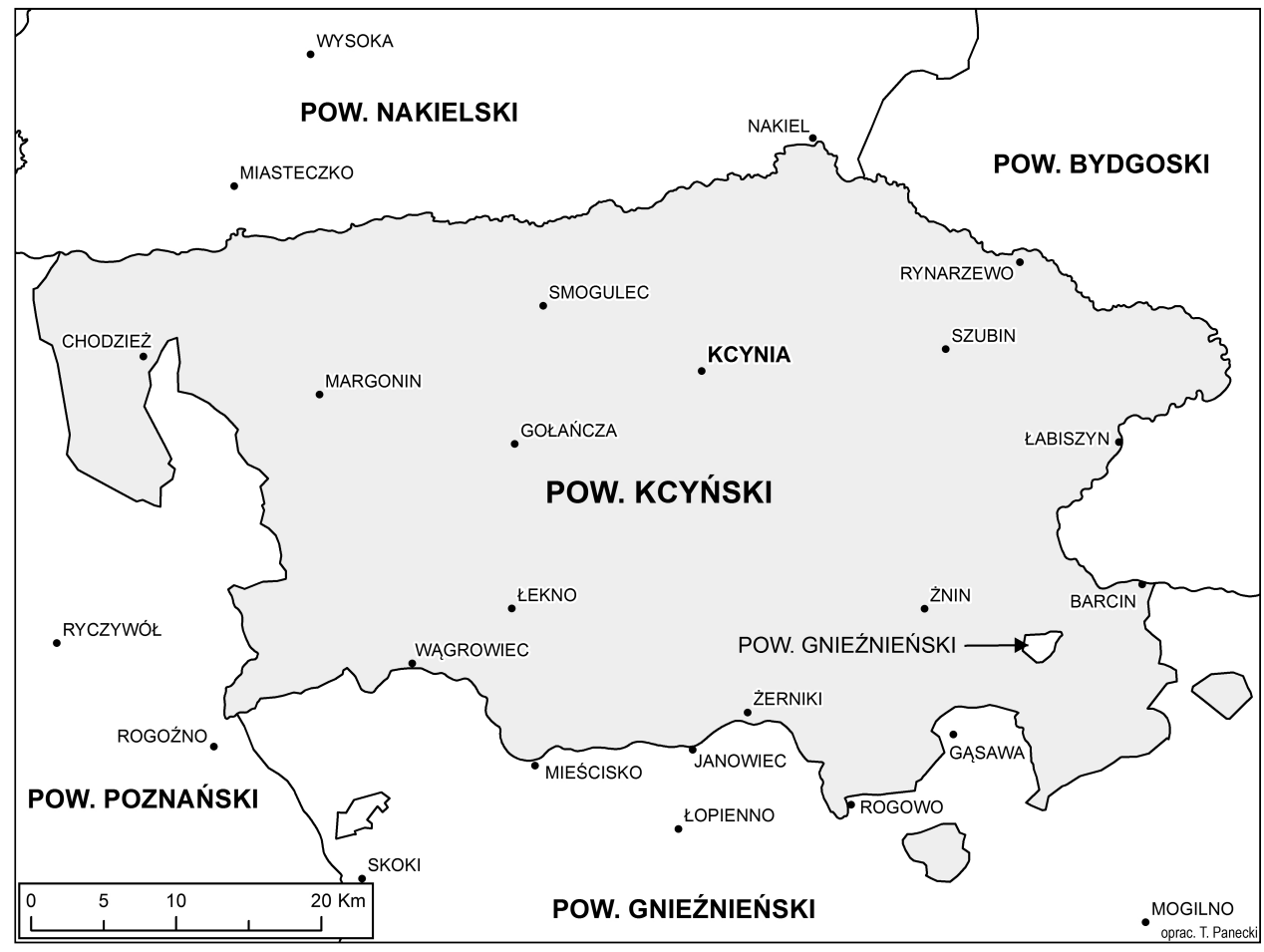

Mapa 1. Powiat kcyński w 2. pot. XVI w.

dobra oskarżonego (actor sequitur forum rei $)^{10}$. Powiat sądowy nie był w swym założeniu pojęciem terytorialnym, lecz przede wszystkim instytucją: do powiatu należał właściciel, a nie jego dobra. Według Antoniego Gąsiorowskiego dla początkowego okresu nie można mówić o ściśle wydzielonych granicach konkretnego powiatu, a i potem określić je można precyzyjnie tylko w tym przypadku, gdy przebiegały między dobrami szlacheckimi ${ }^{11}$. U schyłku XV w. sytuacja ta zaczęła sięzmieniać w związku ze stopniowym upadkiem sądownictwa ziemskiego. Osłabieniu uległa sądowa odrębność powiatu. Jednocześnie rozwijający się aparat fiskalny doprowadził do stopniowego „uterytorialnienia” powiatów ${ }^{12}$. Ze względów praktycznych podział na województwa (a wewnątrz nich na powiaty) zaczęto bowiem wykorzystywać do rejestrowania podatników

10 Tamże, s. 29

11 Tamże, s. 81. Por. też H. Rutkowski, Granice państwowych, s. 27-28.

12 A. Gąsiorowski, Powiat w Wielkopolsce, s. 81. i ściągania podatków obejmujących wszystkie kategorie własności. Stosowanie przez poborców podatkowych podziałów terytorialnych państwa sprawiło, że znane $\mathrm{z}$ rejestrów poborowych tzw. powiaty skarbowe na ogół pokrywały się w Wielkopolsce z podziałem występującym w księgach sądowych ${ }^{13}$. Istniejące w tej materii różnice opisane zostały poniżej.

Granice wschodnia i zachodnia powiatu kcyńskiego były jednocześnie granicami województwa. Od zachodu sąsiadował on z powiatem poznańskim województwa poznańskiego, zaś od wschodu z powiatem bydgoskim województwa inowrocławskiego. Wspomniane granice opierały się w większości na naturalnej sieci hydrograficznej oraz obszarach leśnych i bagiennych. Północna granica powiatu biegła wzdłuż Noteci - od Nakła do wsi Nietuszkowo

\footnotetext{
13 Stownik historyczno-geograficzny województwa poznańskiego w średniowieczu [dalej: SHGP], cz. 1, s. VIII (poszczególne tomy SHGP dostępne są online na stronie: http://www.slownik.ihpan.edu.pl, dostęp: 11 lipca 2015); H. Rutkowski, Granice państwowych, s. 30.
} 
(dawniej Nietąszkowo) w parafii Ujście. Samo miasto Ujście, położone kilka kilometrów dalej na zachód, w miejscu wpływu rzeki Gwdy do Noteci, znajdowało się już w województwie poznańskim. Granica wschodnia powiatu kcyńskiego w całości wiodła Notecią - od Barcina do Nakła. Granicę południową wyznaczała częściowo rzeka Wełna - od Jeziora Rogowskiego oraz Rogówka i Wiewiórczyna na wchodzie po ujście rzeki Rudki na północ od Rogoźna ${ }^{14}$. Widoczne są tu jednak pewne odstępstwa. Przynależności powiatowej dwóch osad położonych na północ od Wełny - Jakubowa i Pokrzywnicy (parafia Pruśce) nie można ustalić jednoznacznie. Jakubowo - w 2. poł. XVI w. najpewniej osada opustoszała - nie występuje w rejestrach poborowych z tego okresu, zaś księgi sądowe najczęściej umieszczają je w powiecie gnieźnieńskim, choć pojawiają się także zapisy notujące je w powiecie kcyńskim. W przypadku Pokrzywnicy rzecz jest jeszcze bardziej niejasna: w rejestrach poborowych występuje ona w powiecie gnieźnieńskim, zaś zdecydowana większość zapisów z ksiąg sądowych od XV do XVII w. umieszcza ją w powiecie kcyńskim ${ }^{15}$. Owo ciążenie obu osad do powiatu gnieźnieńskiego mogło mieć związek z faktem, że były one powiązane własnościowo z pobliskimi osa-

14 A. Gąsiorowski, Powiat w Wielkopolsce, s. 63. Autor omawia szeroko czynniki wpływające na przebieg granic powiatowych, m.in. elementy środowiska naturalnego i stosunki własnościowe istniejące na danym terenie. Tamże, s. 55-82. Por. A. Borek, Powiat kcyński w drugiej połowie XVI w. w: Atlas historyczny Polski. Rejestry poborowe województwa kaliskiego w XVI w., red. M. Słoń (http://atlasfontium.pl/, dostęp: 11 lipca 2015).

15 ASK I 13, k. 138v, 543, 593, 648v; ŹD, 12, s. 153; Teki Dworzaczka: księgi ziemskie poznańskie, XV w.: 7417 (nr 1386), 9622 (nr 9 gr. 1386); księgi ziemskie i grodzkie poznańskie, inskrypcje, XVI w., cz. 1: 915 (nr 863); księgi grodzkie i ziemskie poznańskie, rezygnacje, XVI w.: 4132 (nr 1392), 2280 (nr 1395), 7766 (nr 1396), 9680 (nr 1397), 10859 (nr 1398); księgi grodzkie i ziemskie poznańskie, rezygnacje,XVII w., cz. 1: 4084, 7322 (nr 1410); księgi grodzkie i ziemskie pyzdrskie, cz. 2: 1178, 1179 (nr 23); księgi grodzkie i ziemskie gnieźnieńskie, cz. 1: 2851 (nr 43); księgi grodzkie i ziemskie gnieźnieńskie, cz. 2: 5156, 5342, 5344 (nr 335a); księgi grodzkie i ziemskie nakielskie, cz. 2: 2489, 2577 (nr 215). Leon Polaszewski, opatrując Jakubowo adnotacją o niejasnej przynależności powiatowej, umieszcza je raz w powiecie gnieźnieńskim - w spisie miejscowości szlacheckich, a raz w powiecie kcyńskim - na mapie załącznikowej do swej pracy. Wieś Pokrzywnica znajdowała się według niego w XVI w. w powiecie kcyńskim, do powiatu gnieźnieńskiego należał zaś jedynie młyn przy- dami Pruśce, Marlewo, Sierniki i Wiatrowo położonymi po przeciwnej stronie Wełny ${ }^{16}$.

Granica południowa powiatu kcyńskiego na wschód od Rogówka nie opierała się już na barierach naturalnych. W jednym miejscu wsie należące do powiatu kcyńskiego - Ryszewo i Ryszewko (par. Ryszewko) - otoczone były ze wszystkich stron wsiami powiatu gnieźnieńskiego ${ }^{17}$. W przypadku wsi Słaboszewo i Krzekotowo zdecydowano się przyjąć inną przynależność powiatową niż ta, która odnotowana była w rejestrach poborowych. Według tych zapisów parafia Słaboszewo podzielona była administracyjnie między powiaty kcyński i gnieźnieński. Do powiatu kcyńskiego należały wsie Słaboszewko i Radłowo, zaś do gnieźnieńskiego - Słaboszewo i Krzekotowo ${ }^{18}$. Taką samą przynależność powiatową Słaboszewka i Radłowa jak rejestry notują też księgi sądowe, natomiast Krzekotowo umieszczają one w powiecie kcyńskim ${ }^{19}$. Wieś Słaboszewo należąca do arcybiskupstwa gnieźnieńskiego nie pojawia się $\mathrm{w}$ świeckich źródłach sądowych. Wchodziła ona w skład dóbr arcybiskupiego klucza żnińskiego, stąd przypuszczać można, że również ona ciążyła do powiatu kcyńskiego ${ }^{20}$. Dlatego też przyjęliśmy, że w omawianym czasie zarówno Krzekotowo, jak i Słaboszewo należały do powiatu kcyńskiego, dopuszczając

należny do tej wsi. L. Polaszewski, Własność feudalna w województwie kaliskim w XVI w., Poznań 1976, s. 169, 190.

16 Na duże znaczenie stosunków własnościowych dla przebiegu granic powiatowych (choć tylko w przypadku własności szlacheckiej) wskazuje Antoni Gąsiorowski. A. Gąsiorowski, Powiat w Wielkopolsce, s. 73-79.

17 Mimo że przeważają wpisy notujące przynależność Ryszewa do powiatu kcyńskiego, niektóre zapisy w księgach sądowych umieszczają je też w powiecie gnieźnieńskim. Teki Dworzaczka, księgi grodzkie i ziemskie gnieźnieńskie, cz. 2: 4897, 4979, 5338 (nr 335a), 833 (nr 263). Podobnie notuje tę wieś rejestr poborowy z lat 1618-1620, umieszczając ją w parafii Gościeszyn. Rp1618, s. 193, 256. Zapiska z 1606 r. stwierdza natomiast, że Ryszewo należy do powiatu gnieźnieńskiego lub kcyńskiego. Teki Dworzaczka, księgi grodzkie i ziemskie poznańskie, rezygnacje, XVII w., cz. 1: 1441 (nr 1405). Ryszewko, jako że stanowiło własność klasztoru kanoników regularnych w Trzemesznie, nie pojawia się w świeckich księgach sądowych.

18 Zob. edycję elektroniczną rejestrów poborowych obu powiatów (http:// atlasfontium.pl/, dostęp: 12 lipca 2015).

19 Teki Dworzaczka, księgi grodzkie i ziemskie gnieźnieńskie, cz. 2: 4828 (nr 335a), 6428 (nr 31), 6744 (nr 32); księgi grodzkie i ziemskie nakielskie, cz. 2: 2533 (nr 215). Por. L. Polaszewski, Własność feudalna, s. 188, 191.

20 Wizytacje dóbr arcybiskupstwa, s. 298-299. 


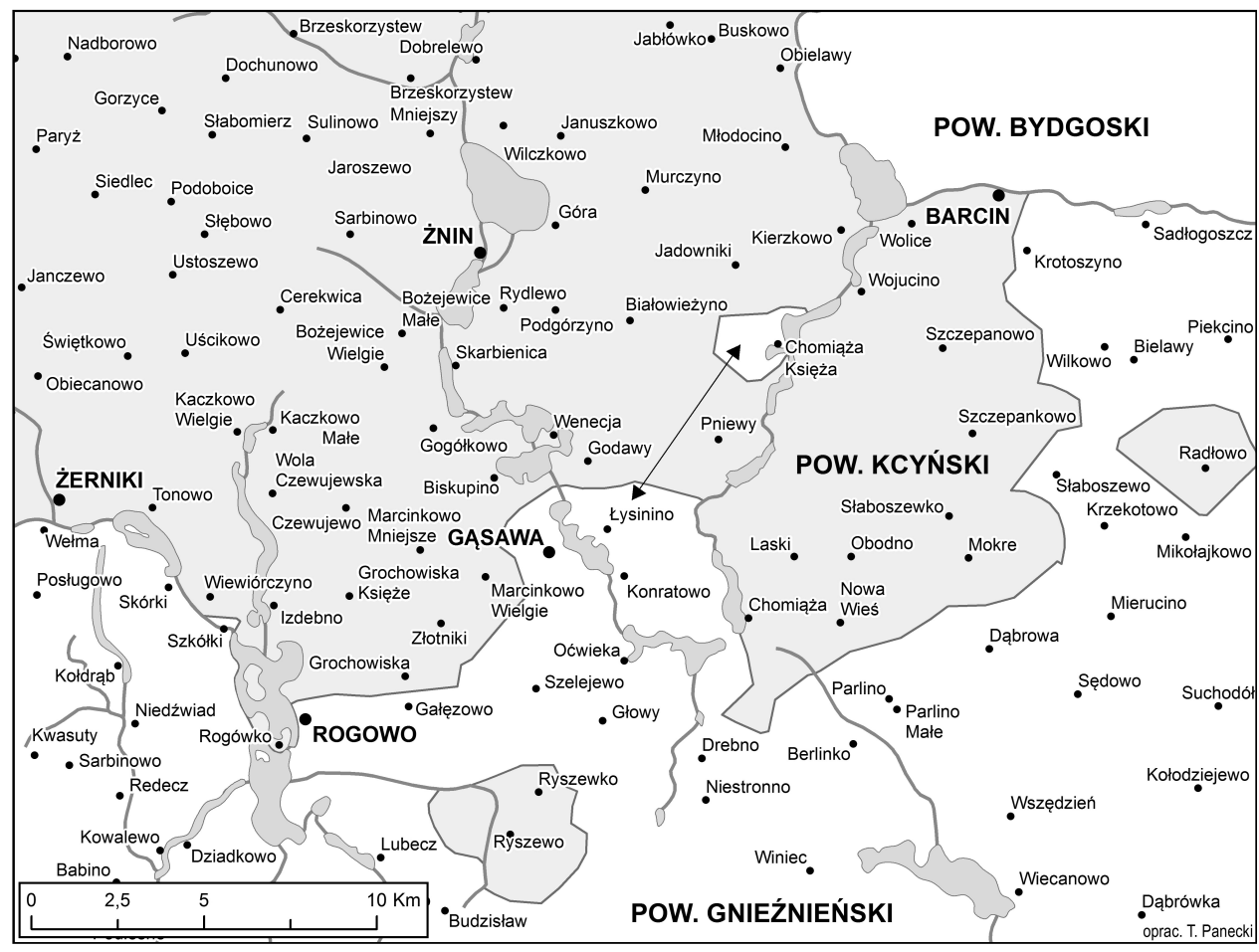

Mapa 2. Granica powiatów kcyńskiego, gnieźnieńskiego i bydgoskiego w końcu XVI w.

jednak także ich alternatywną przynależność do powiatu gnieźnieńskiego ${ }^{21}$. Wieś Chomiążę Księżą (parafia Ostroszcze) rejestry poborowe notują $\mathrm{w}$ powiecie gnieźnieńskim ${ }^{22}$. Działo się tak być może ze względu na wygodę płatnika poboru, którym była tu sufragania gnieźnień$\mathrm{ska}^{23}$. Znaczne oddalenie tej wsi od granicy powiatowej oraz brak innych źródeł potwierdzających istnienie tego rodzaju eksklawy administracyjnej skłania do dopuszczenia założenia, że Chomiąża Księża znajdowała się w owym czasie w granicach powiatu kcyńskiego ${ }^{24}$.

21 Przynależność Krzekotowa i Słaboszewa do powiatu gnieźnieńskiego, zgodnie z zapisem z rejestrów poborowych, przyjmuje mapa Ziemie polskie Korony w XVI w. Przestrzenna baza danych, Instytut Historii PAN im. Tadeusza Manteuffla (http://atlasfontium.pl/, dostęp: 12 lipca 2015). 22 ASK I 3, 425; ASK I 13, 26.

23 LBG I, s. 180; Teki Dworzaczka: księgi grodzkie i ziemskie gnieźnieńskie, cz. 1: 4609 (nr 60), 1582 r.; L. Polaszewski, Własność feudalna, s. 93. Chomiąża należała do probostwa w Żninie, które na pocz. XVI w. wydzielono (razem z probostwem w Uniejowie) jako uposażenie sufraganowi gnieźnieńskiemu. J. Korytkowski, Prałaci i kanonicy katedry metropolitalnej gnieźnieńskiej od roku 1000 aż do dni naszych, t. 1 , Gniezno 1883, s. 53-54. Inne wsie należące do probostwa w Żninie
Zachodnia granica powiatu kcyńskiego w XV i 1. poł. XVI w. wykazywała pewne wahania, zwłaszcza w okolicach Chodzieży. Od lat 60. XVI w. jednak, jak się wydaje, była już ustalona. Budzyń, Podstolice i Brzekiniec - należące pierwotnie do powiatu kcyńskiego i stanowiące początkowo osobną tenutę królewską - zmieniły przynależność na rzecz powiatu poznańskiego, co wiązało się zapewne z przyłączeniem ich do dóbr starostwa rogozińskiego ${ }^{25}$. Przebieg granicy między oboma powiatami odnotowany przez rejestry poborowe

i stanowiące wraz z nim uposażenie sufragana gnieźnieńskiego (Rydlewo i Skarbienice) rejestry poborowe notują jednak konsekwentnie w powiecie kcyńskim. Stąd też wyjaśnienie, dlaczego Chomiążę poborcy podatku spisywali razem z wsiami powiatu gnieźnieńskiego, wymaga dalszych poszukiwań źródłowych.

24 Inaczej przyjmuje Marek Słoń. M. Stoń, Powiat gnieźnieński w drugiej połowie XVI w., w: Atlas historyczny Polski. Rejestry poborowe województwa kaliskiego w XVI w., red. M. Stoń (http://atlasfontium.pl/, dostep: 12 lipca 2015).

25 SHGP, cz. 1, hasła: Brzekiniec, s. 124; Budzyń, s. 137-138; cz. 3, hasło: Podstolice, s. 718-719. 
z lat 1564-1591 nie wykazuje już żadnych wahań, nie podlegając zmianom aż do pierwszego rozbioru Rzeczypospolitej w 1772 r. W sposób jednoznaczny nie można ustalić jedynie przynależności powiatowej nieistniejącej już wsi Kaława (parafia Chodzież), należącej do starostwa ujskiego i położonej niecałe $10 \mathrm{~km}$ na południowy zachód od Chodzieży ${ }^{26}$. W 2. poł. XVI w. zachodnia granica powiatu kcyńskiego biegła zatem od południa początkowo w górę rzeki Rudka, potem zaś rzeką Dymnicą (dawniej Tumienica) do granic wsi Brzekiniec, pozostawiając ją po stronie powiatu poznańskiego, zaś po stronie powiatu kcyńskiego - Sarbkę (dawniej Sarpka) i Dziewoklucz. Następnie granica ta odbijała nieco na północny zachód, w stronę Chodzieży - oddzielając położone w powiecie kcyńskim wsie Radwanki, Pietronki (dawniej Piotrmanki) i miasto Chodzież od Podstolic, Podanina i Rataj ${ }^{27}$ znajdujących się w powiecie poznańskim - a następnie szła na południe granicami osad Ostrówki (dawniej Ostrówek, powiat kcyński) i Prosna (powiat poznański). Na przebieg granicy powiatowej w tym miejscu wpływ miały zapewne warunki naturalne terenu, a mianowicie rozległy obszar puszczański, którego pozostałości istnieją do dziśs ${ }^{28}$. Układ granic wiązał się być może również z podziałami własnościowymi tego terenu. Jak wspomniano, Podstolice, Po-

26 Por. SHGP, cz. 2, hasło: Kaława, s. 105-106 (tam też przypuszczalna lokalizacja tej wsi). Zob. też F. Żmidziński, Osadnictwo w starostwie ujsko-pilskim do roku 1772, „Rocznik Nadnotecki”, 1, 1966, s. 49-53; Ziemie polskie (zob. przyp. 21).

27 Przekazy źródłowe z XV i 1. poł. XVI w. różnie określają przynależność powiatową Rataj, jednak niemal wszystkie rejestry poborowe od 2. poł. XVI w. (oprócz rejestru z 1564 r.) umieszczają tę osadę w powiecie poznańskim. Zob.: SHGP, cz. 4, s. 41; Atlas historyczny Polski. Rejestry poborowe województwa poznańskiego w XVI w. red. M. Słoń (http://atlasfontium.pl/, dostęp: 12 lipca 2015).

28 Rozległa puszcza należąca do starostwa rogozińskiego rozciągała się od Dziewoklucza po królewską wieś Tłukawy (powiat poznański) oraz między Podstolicami a wsią Laskowo (powiat poznański) stanowiącą własność plebana kościoła parafialnego w Rogoźnie. Lustracja województw wielkopolskich i kujawskich 1564-1565 [dalej: LWK], cz. 1, wyd. A. Tomczak, C. Ohryzko-Włodarska, J. Włodarczyk, Bydgoszcz 1961, s. 248. Granica między 0strówkami a Prosną wiodła strugą o nazwie Miąsza; opis tej granicy zob. SHGP, cz. 3, s. 110-111.

29 Opis przebiegu granicy między wsiami królewskimi Rataje i Podanino (stanowiącymi własność starostwa ujskiego) a Chodzieżą i Studzieńcem Potulickich notuje lustracja dóbr królewskich z lat danin i Budzyń stanowiły własność królewską; miasto Chodzież oraz okoliczne wsie: Stróżewo, Studzieniec, Milcz, Słomki (dawniej Słąki), Kamionka, Ciszewo (dawniej Czeszewo) i Ostrówki wraz z Hutą Ostrowską należały w omawianym czasie do Potulickich, zaś Pietronki i Radwanki - do Radwanowskich ${ }^{29}$. Za Hutą granica obierała kierunek południkowy, biegnąc zapewne strugą wiodącą ku jezioru Karczewnik (dawniej Średnie), widoczną jeszcze wyraźnie na mapie Friedricha Leopolda von Schröttera ${ }^{30}$. Następnie, pozostawiając wsie Oleśnica i Nietuszkowo (dawniej Nietąszkowo) po stronie powiatu kcyńskiego, docierała do Noteci.

Omówienie zagadnienia, w jakim stopniu granice XVI-wiecznego powiatu kcyńskiego pokrywały się z granicą historycznych Pałuk, wykracza poza ramy niniejszego artykułu. Kwestia ta była już jednak wielokrotnie poruszana w badaniach na temat tego regionu. Podsumowując te rozważania, można stwierdzić, że większość badaczy uważa, iż historyczna ziemia pałucka sięgała nieco dalej na południowy wschód i wschód, obejmując także m.in. Gąsawę czy Pakość, zaś na zachodzie jej granicę wyznaczała rzeka Margoninka ${ }^{31}$.

Rejestry poborowe są istotnym źródłem do odtworzenia przebiegu granic administracji państwowej. W przypadku rekonstrukcji gra-

1564-1565. Biegła ona rzeczką Bolemką: od jej źródeł przy młynie Krąpka i młynie miejskim Chodzieży aż do gruntów wsi Rataje i dzisiejszego Jeziora Chodzieskiego, dzieląc je na pół. Bolemka przepływała przez to jezioro i dalej rozdzielała Rataje i Chodzież, dochodząc do rozległego błota, a następnie szła jego środkiem aż do wsi Studzieniec, w pobliżu której Potuliccy zagarnęli niegdyś łąki, brzeg Noteci oraz wielki ostrów należące do wsi Rataje, przyłączając je do swych majętności. LWK I, s. 207. Do Potulickich należały także inne wsie położone między Margoninem a Gołańczą: Sypniewo, Sułaszewo, Próchnowo, Kowalewo, Grabowo, Konary, Oporzyn i Tomiszewo. S. Chmielewski, Od lokacji miasta do połowy XVII w. [1434-1654], w: Dzieje Chodzieży, red. S. Chmielewski, Chodzież 1998, s. 66-70. Por. też przyp. 85

30 Karte von Ost-Preussen nebst preussisch Litthauen und West-Preussen nebst dem Netzdistrict aufgenommen unter Leitung des königl. Preuss. Staats Ministers Frey Herrn von Schroetter in den Jahren 1796 bis 1802, Berlin 1802-1812, sek. $20+24$.

31 A.M. Wyrwa, Pałuki, s. 16-22 (wraz z mapą na s. 21); A. Wędzki, Pałuki w średniowieczu, Żnin 1998 (Dzieje Pałuk, 2), s. 8-10; A. Klonder, Pałuki w dobie wczesnonowożytnej, Gołańcz 2008 (Dzieje Pałuk, 3), s. 9. Por. P. Klint, Szlachecki obrót, s. 21-23. 


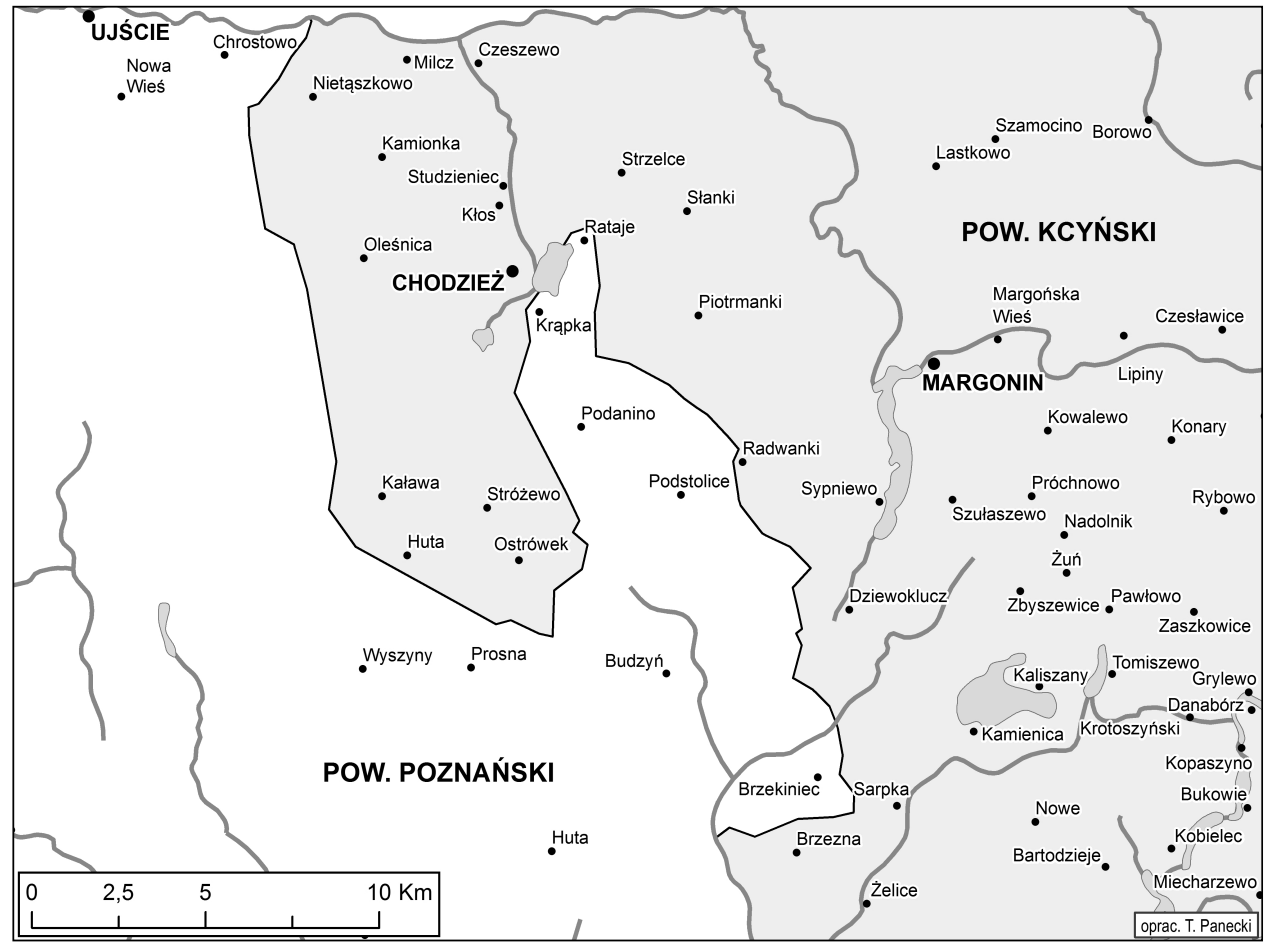

Mapa 3. Granica powiatów kcyńskiego i poznańskiego w końcu XVI w.

nic parafialnych możemy je jednak traktować jedynie pomocniczo - w razie niedostatku bądź niejasności źródeł kościelnych ${ }^{32}$. Przebieg granic administracji kościelnej (diecezja, archidiakonat, dekanat, parafia) pozwalają odtworzyć wizytacje diecezjalne ${ }^{33}$. Teren powiatu kcyńskiego w omawianym okresie podzielony był między trzy diecezje: gnieźnieńską, poznańską i włocławską. Zdecydowana większość obszaru należała do archidiakonatu gnieźnieńskiego archidiecezji gnieźnieńskiej, a wewnątrz niego do trzech dekanatów: Łekno, Żnin i Gniezno-

\footnotetext{
32 Por. I. Gieysztorowa, Źródła i szacunki, s. 576.

33 Do rekonstrukcji granic jednostek administracji kościelnej istniejących na terenie powiatu kcyńskiego w 2. poł. XVI w. wykorzystano następujące wizytacje: „Akta wizytacji archidiakonatu gnieźnieńskiego Wincentego de Seve 1608-1609", Archiwum Archidiecezjalne w Gnieźnie, sygn. E 40, k. 47v-51v, 58v-104, 295-328, 336v-338v (mf. ABMK 3812); „Wizytacja archidiakonatu poznańskiego 1628-1629”, Archiwum Archidiecezjalne w Poznaniu, sygn. AV 7, k. 3-5, 16v, 21v, 40-41 (mf. ABMK 367); Visitatio ecclesiarum in archidiaconatu dioecesis Wladislaviensis consistentium per [...] Stanislaum Karnkowski episcopum Wladislaviensem et Pomeraniae [... facta anno 1577 [...], w: Monumenta Historica Dioeceseos WIadislaviensis [dalej: MHDW],
}

-św. Piotr. Dekanat Łekno zajmował zachodnią połowę powiatu i obejmował 18 parafii w całości położonych na jego terenie (Chojna, Czeszewo, Dziewierzewo, Gołańcz, Grelewo, Jaktorowo, Kcynia, Kozielsko, Łekno, Panigródz, Rynarzewo, Słupy, Smogulec, Srebrna Góra, Szaradowo, Szubin, Tarnowo, Żoń) oraz 2 parafie, do których należały także wsie spoza powiatu (Samoklęski i Wagrowiec) ${ }^{34}$. Dekanat Żnin, któremu podlegała wschodnia część powiatu, obejmował 14 parafii w całości położonych na jego terenie (Brzyskorzystew,

vol. 17, Wladislaviae 1899, s. 122-123; Visitatio ecclesiarum dioecesis Wladilaviensis per [...] Mathiam Karski [...] de mandato [...] Stanislai Karnkowski ep. WI. facta anno 1578 [...], w: MHDW, vol. 17, s. 21-22, 33; Visitatio archidiaconatus Wladislaviensis [...] facta 1582 a., w: MHDW, vol. 19, Wladislaviae 1900, s. 65-66. Informacji uzupełniających dostarczają księgi uposażeń biskupstw poznańskiego i gnieźnieńskiego. Zob. przyp. 2

34 W parafii Samoklęski znajdowały się wsie należące do powiatu bydgoskiego województwa inowrocławskiego - Gorzeń i Żurczyn. LBG I, s. 129. Nie wliczono tu parafii Stępuchowo, która już na pocz. XVI w. wakowała, a przed $1608 \mathrm{r}$. włączona została do parafii w Kozielsku. Tamże, s. 109, 142-143; E 40, k. 104 
Cerekwica, Chomętowo, Chomiąża Szlachecka, Gorzyce, Góra Arcybiskupia, Izdebno, Janczewo, Kierzkowo, Słaboszewo, Świątkowo, Wenecja, Żerniki i Żnin); trzy parafie, do których należały także wsie spoza powiatu (Ostroszcze, Ryszewko i Szczepanowo), oraz dwie parafie z siedzibami w powiecie gnieźnieńskim, w skład których wchodziły także wsie z powiatu kcyńskiego (Rogowo i Gąsawa) ${ }^{35}$. Do dekanatu Gniezno-św. Piotr należały miejscowości położone na prawym brzegu Wełny, podzielone między dwie parafie, których siedziby (Mieścisko i Janowiec) znajdowały się po południowej stronie rzeki w powiecie gnieźnieńskim. Położone nad Notecią we wschodniej części powiatu miasto Barcin należało do dekanatu inowrocławskiego podlegającego archidiakonatowi kruszwickiemu diecezji włocławskiej. Przynależność kościelna nadnoteckiego Łabiszyna w omawianym czasie była bardziej skomplikowana. Miasto położone na lewym brzegu Noteci, wraz z kościołem parafialnym św. Mikołaja i szpitalnym kościołem św. Ducha, podlegało diecezji gnieźnieńskiej. Usytuowane na przeciwnym brzegu rzeki przedmieście razem z trzema swymi kościołami znajdowało się $\mathrm{w}$ granicach dekanatu inowrocławskiego $^{36}$. Z kolei zachodnie krańce powiatu kcyńskiego obejmował wówczas dekanat obornicki wchodzący w skład archidiakonatu poznańskiego w diecezji poznańskiej ${ }^{37}$. Należały do niego osady z pięciu parafii: Margonina, Potulic, Chodzieży, Ujścia i Łęgowa. Parafie Margonin i Potulice w całości położone były na terenie powiatu kcyńskiego. W granicach para-

35 W wykazie uwzględniono parafię Ostroszcze, mimo że już w końcu XVI w. tamtejszy kościół parafialny nie spełniał swych funkcji duszpasterskich - urząd plebana był nieobsadzony, świątynia niszczała a wierni przyjmowali sakramenty w innych parafiach. E 40, k. 308v.

36 MHDW, vol. 17, s. 21; R. Nowicki, Z przeszłości Łabiszyna, Łabiszyn 1997, s. 5-6. Zarówno w przypadku Łabiszyna, jak i Barcina wszystkie wsie należące do parafii położone były już na prawym brzegu №teci, w powiecie bydgoskim województwa inowrocławskiego. ŹD, 12, s. 258

37 Około 1602 r. nastąpił nowy podział archidiakonatu poznańskiego na dekanaty. Utworzono wówczas nowe, m.in. Czarnków i Rogoźno. Wizytacja z 1628 r., która stanowiła podstawę rekonstrukcji sieci parafialnej w omawianym okresie, przeprowadzona została już według nowego podziału. J. Nowacki, Dzieje archidiecezji poznańskiej, t. 2 , Poznań 1964, s. 324-325; SHGP, cz. 3, s. 374, hasło: Oborniki dekanat. fii w Chodzieży znajdowały się natomiast także cztery osady z powiatu poznańskiego: Podanin, Podstolice, Prosna i Wyszyny ${ }^{38}$. Usytuowane nad Notecią Nietuszkowo podlegało parafii w Ujściu, a wieś Bobrowniki, stanowiąca własność cystersów w Wągrowcu, należała do parafii w Łęgowie (powiat gnieźnieński) ${ }^{39}$.

W omawianym okresie na terenie powiatu kcyńskiego siedziby miało 41 parafii, wśród których przeważały kilkuwioskowe; w tym czasie notujemy tam tylko dwie jednowioskowe - Jaktorowo i Kierzkowo. Największa była parafia w Kcyni, której zasięg oprócz miasta i jego przedmieść obejmował aż 24 osady, oraz parafia w Chodzieży, w skład której wchodziło 20 miejscowości. 5 miejscowości na terenie powiatu było podzielonych między dwie parafie w ten sposób, że wieś podlegała jednej, a dwór z folwarkiem drugiej. Do parafii w Kozielsku należały dwory w Dąbrowie, Starężynie i Starężynku, zaś same wsie - do parafii w Juncewie (dawniej Janczewo). W skład parafii kozielskiej wchodziły także dwory w Żużołach i Niemczynie (dawniej Miemczyn); pierwsza z tych wsi należała natomiast do parafii w Żernikach, a druga do parafii w Łeknie ${ }^{40}$.

Powiat kcyński zajmował $\mathrm{w}$ omawianym okresie obszar nieco ponad $2400 \mathrm{~km}^{2}$, co czyniło go drugim po powiecie konińskim $\left(2375 \mathrm{~km}^{2}\right)$ wśród najmniejszych w województwie kaliskim ${ }^{41}$. Również pod względem liczby osad zajmował drugie miejsce od końca - po

\footnotetext{
38 W omawianym czasie do parafii Potulice należał także być może Brzekiniec (powiat poznański), tak jak to notuje LBP (s. 89). Wizytacja z lat 1628-1629 nie wymienia go jednak w spisie osad należących do tej parafii. AV 7, k. 41. Por. SHGP, cz. 1, s. 123-124, hasło: Brzekiniec. Zob. też S. Kozierowski, Szematyzm historyczny ustrojów parafialnych dzisiejszej archidiecezji poznańskiej, Poznań 1935, s. 300-301. Na mocy dokumentów z lat 1559 i 1561 biskup poznański Andrzej Czarnkowski wyłączył wsie Prosna i Wyszyny z parafii Chodzież i włączył je do parafii Ryczywół aż do czasu powrotu kościoła w Chodzieży w ręce katolików. SHGP, cz. 3 , s. 818, hasło: Prosna. Kościół chodzieski był w posiadaniu innowierców do 1589 r. Prosna powróciła wówczas do parafii chodzieskiej, zaś Wyszyny na przemian podlegały jeden rok parafii Ryczywół, a drugi parafii Chodzież. L. Kurpisz, Kronika kościołów chodzieskich, Chodzież 1933, s. 21. Zob. też J. Nowacki, Dzieje archidiecezji, t. 2, s. 381, 383.

39 J. Nowacki, Dzieje archidiecezji, t. 2, s. 380, 384; SHGP, cz. 3, s. 281, hasło: Nietąszkowo.

40 LBG I, s. 106-108, 140-142, 162; E 40, k. 59, 102, 313, 318.

41 Największy był powiat nakielski - $3234 \mathrm{~km}^{2}$, następnie kaliski 3186 km², gnieźnieński - 3109 km² i pyzdrski - 2808 km².
} 
najmniej ludnym powiecie nakielskim. Liczba miejscowości w powiecie kcyńskim odnotowanych w poszczególnych rejestrach poborowych z 2. poł. XVI w. wykazuje nieznaczne różnice. W sumie na podstawie rejestrów poborowych $\mathrm{z}$ tego okresu, po uzupełnieniu ich danymi z innych źródeł, liczbę znanych punktów osadniczych możemy określić na $319^{42}$. Leon Polaszewski, który przeanalizował w swych badaniach także informacje z ksiąg sądowych i źródeł kościelnych, podaje liczbę 365 osad, lecz są to dane dla całego XVI w. ${ }^{43} \mathrm{Na}$ obecnym etapie badań nad siecią osadniczą powiatu kcyńskiego trwa jeszcze analiza i weryfikacja dostępnego poza rejestrami poborowymi materiału źródłowego. Ich celem jest ustalenie ostatecznej liczby osad istniejących w powiecie kcyńskim w 2. poł. XVI stulecia. Szczególne trudności interpretacyjne sprawiają miejscowości dobrze poświadczone dla XV i pocz. XVI w. i następnie dopiero dla XVIII w. Trzeba bowiem ustalić, czy miejscowości te w omawianym okresie opustoszały i zanikły, a ponowne ich zasiedlenie w późniejszych wiekach wiązało się już z nową falą kolonizacji. W wielu przypadkach jednak brak danej osady w źródłach skarbowych z 2. poł. XVI i pocz. XVII w. łączyć się może z jej przekształceniem w folwark. Dotychczasowe prace pozwoliły zlokalizować kilkanaście punktów osadniczych, które nie pojawiają się w rejestrach poborowych - przede wszystkim osad młyńskich $\mathrm{z}$ własna nazwą oraz folwarków. Lokalizację części osad można ustalić tylko w przybliżeniu, część zaś określić możemy jedynie jako niezlokalizowane, lecz w sposób pewny istniejące w 2 . poł. XVI w.

Zestawiając dotychczas zweryfikowane dane dotyczące liczby miejscowości w ówczesnym powiecie kcyńskim z jego obszarem, można stwierdzić, że jedna osada przypadała tu na ok.

\footnotetext{
42 A. Borek, Powiat kcyński. W latach 1626-1655, zgodnie z szacunkami Pawła Klinta, na terenie powiatu kcyńskiego istniała zbliżona liczba osad - 312. P. Klint, Szlachecki obrót, s. 26-27 oraz Aneks, s. 221-338. Badacz ten zalicza jednak do powiatu kcyńskiego wsie Podanin i Rataje. Tamże, s. 33

43 L. Polaszewski, Własność feudalna, s. 62, tab. 3. Por. uwagi krytyczne na ten temat w recenzji tej pracy pióra Andrzeja Nowaka. „Rocznik Kaliski", 11, 1978, s. 293.
}

$7,5 \mathrm{~km}^{2}$. Dla porównania w tym czasie w większym o ok. $20 \%$ powiecie nakielskim jedna osada przypadała na ok. $18 \mathrm{~km}^{2}$.

Sieć osadnicza powiatu kcyńskiego w zasadniczym stopniu ukształtowała się już w okresie średniowiecza (XIII-XV w.). Przyrost nowych osad w XVI w., a zwłaszcza w drugiej połowie tego stulecia był już niewielki i dotyczył przede wszystkim obszarów peryferyjnych. W tym czasie nasilił się natomiast proces pustoszenia osad oraz ich przemiany w folwarki. Najstarsze i zarazem największe skupiska osad znajdowały się w centralnej części powiatu, między Margoninem, Żoniem i Wągrowcem na zachodzie a Kcynią, Słupami, Żninem i Wenecją na pótnocnym wschodzie i wschodzie. Leżące na obrzeżach powiatu kcyńskiego tereny charakteryzujące się przewagą obszarów leśno-łąkowych były zasiedlone późno i rzadziej. Na terenie powiatu istniały także duże połacie puszcz oraz bagien, które aż do XVIII w. nie były zasiedlone. Obszary podmokłe znajdowały się zwłaszcza w dolinie Noteci, szeroki pas bez osad ciągnąt się od Nakła aż do okolic Chodzieży. Zwarte kompleksy puszczańskie rozciągały się na lewym brzegu Noteci, na jej odcinku między Łabiszynem a Rynarzewem, sięgając na zachód aż do Szubina i dalej między Szubinem, Gromadnem (parafia Smogulec), Polichnem (dawniej Polikno) a Samoklęskami we wschodniej części powiatu oraz między Smogulcem, Margoninem a Szamocinem w część środkowej. Gęstymi lasami, których znaczna część istnieje do dziś, porośnięte było pogranicze powiatów kcyńskiego i poznańskiego, zwłaszcza obszar między Sypniewem, Dziewokluczem a Budzyniem oraz na zachód od Chodzieży ${ }^{44}$.

Rejestry poborowe z 2. poł. XVI w. notują w powiecie kcyńskim 11 miast. Jego stolica Kcynia stanowiła własność królewską, ale

\footnotetext{
44 K.J. Hładyłowicz, Zmiany krajobrazu i rozwój osadnictwa w Wielkopolsce od XIV do XIX wieku, Lwów 1932, s. 58-60, 88-89, 127-135 oraz mapa; A. Wędzki, Pałuki, s. 56-57. Na temat środowiska naturalnego omawianego terenu zob. też L. Kozacki, Charakterystyka środowiska przyrodniczego Pałuk, w: Osadnictwo $i$ architektura w rejonie Łekna we wczesnym średniowieczu, red. A.M. Wyrwa, Poznań 1989 (Studia i Materiały do Dziejów Pałuk, 1), s. 23-42.
} 
w omawianym okresie znajdowała się w zastawie, dlatego nie była lustrowana w latach 1564 $1565^{45}$. Dwa miasta były własnością kościelną. Wagrowiec należał do tamtejszego opactwa cysterskiego. Żnin, ówcześnie największe miasto powiatu, wchodził w skład dóbr stołowych arcybiskupa gnieźnieńskiego. Pozostałych osiem miast - Rynarzewo, Szubin, Łabiszyn, Barcin, Żerniki, Łekno, Margonin i Chodzież - należało do szlachty. Ustalenie, czy w omawianym okresie miastami były nadal także Czeszewo, Gołańcz (dawniej Gołańcza), Smogulec, Srebrna Góra (dawniej Srebrna Górka), Stępuchowo (dawniej Stopachowo), wymaga dużej ostrożności badawczej. Miejski charakter tych osad jest poświadczony źródłowo dla XV i 1 . poł. XVI w. ${ }^{46}$ Przekazy z 2. poł. XVI w. są trudne do interpretacji, gdyż wspomniane miejscowości określane są w nich zamiennie bądź jako miasto, bądź jako wieś. Takie zapisy wynikają również z faktu, że w przypadku Czeszewa, Gołańczy i Smogulca obok miasta istniała też wieś o tej samej nazwie ${ }^{47}$. Na tym etapie badań, zdając sobie sprawę z ułomności tego kryterium, jako rozstrzygający przyjęto zapis

45 Starostów (tenutariuszy) kcyńskich w omawianym czasie zestawia Krzysztof Chłapowski: K. Chłapowski, Starostowie w Wielkopolsce, na Kujawach i Mazowszu 1565-1696 (materiały źródłowe), Warszawa 2007, s. 23-24. Dla okresu wcześniejszego analogiczny wykaz opracował Antoni Gąsiorowski: A. Gąsiorowski, Starostowie wielkopolskich miast królewskich $w$ dobie jagiellońskiej, Warszawa-Poznań 1981, s. 40-41. Na temat okresu późniejszego, tj. 1. poł. XVII w., zob. też P. Klint, Szlachecki obrót, s. 33, 259.

46 LBG I, s. 117, 121, 137-138, 142; kartoteka SHGWp - odpowiednie hasła; A. Wędzki, Rozwój sieci miejskiej na Pałukach w średniowieczu, w: tenże, Przechadzki po Wielkopolsce, Poznań 2007, s. 133-143. W średniowieczu ośrodkami miejskimi były także zapewne Wenecja i Żoń (dawniej Żuń), jednak pominięto je tutaj, gdyż Liber beneficiorum Łaskiego określa je już jako wsie.

47 Według Andrzeja Wędzkiego w przypadku Smogulca, a także Margonina i Szubina w momencie lokacji miasta utworzono zapewne „odrębną jednostkę osadniczą typu wiejskiego", do której przeniesiono ludność rolniczą zamieszkującą tereny, na których wytyczono miasto. Nowe osady byly lokowane w pewnej odlegtości od nowo założonego miasta. Następowało także zróżnicowanie w nazewnictwie - do nazwy dodawano człon „wieś", zaś sama forma rzeczownikowa zmieniała się na przymiotnikową: Smogulecka Wieś, Margońska Wieś, Szubska Wieś. W przypadku Gołańczy zdaniem Wędzkiego takie zjawisko nie nastąpito. Miasto wytyczono tu obok dawnej przedlokacyjnej wsi. A. Wędzki, Okres staropolski, w: Gotańcz. Z dziejów miasta i regionu, red. A. Wędzki, Gołańcz 2001, s. 36.

48 Gołańcz została określona jako oppidum (E 40, k. 69), zaś Smogulec jako oppidulum (k. 72). 0 Czeszewie wizytacja wspomina, że niegdyś było miasteczkiem, a teraz jest wsią (k. 100v). Zob. też: A. Klonder, wizytacji biskupiej z 1608 r., który spośród wymienionych wyżej ośrodków miastami nazywa jedynie Gołańcz i Smogulec ${ }^{48}$. Oba te miasta $\mathrm{w}$ omawianym okresie stanowity własność szlachecką. W sumie zatem na terenie powiatu kcyńskiego w 2. poł. XVI w. funkcjonowało 13 ośrodków miejskich. Jedno miasto przypadało tu na ok. $185 \mathrm{~km}^{2}$, co stawiało powiat kcyński na czwartym miejscu pod względem gęstości sieci miejskiej w województwie kaliskim - po powiatach pyzdrskim, gnieźnieńskim i konińskim, gdzie jedno miasto przypadało odpowiednio na 156, 163 i $170 \mathrm{~km}^{2}$. Gęstość sieci miejskiej w powiecie kcyńskim była zatem wyższa niż szacowana średnio dla całej Wielkopolski (jedno miasto na $218 \mathrm{~km}^{2}$ ), będącej najbardziej zurbanizowaną częścią Korony ${ }^{49}$.

Wedle założeń przyjętych w „Atlasie historycznym Polski” ośrodki miejskie liczące 1000 i więcej mieszkańców oznaczamy jako miasta, zaś poniżej tej liczby - jako miasteczka. Zgodnie z tymi kryteriami w 2. poł. XVI w. w powiecie kcyńskim funkcjonowały 3 miasta (Żnin, Wągrowiec i Kcynia) i 10 miasteczek $^{50}$.

Pałuki, s. 49 i n.; A. Wędzki, Okres staropolski, s. 31-37, 48-49. Do uznania Smogulca za miasteczko - wbrew zapisom rejestrów poborowych - skłania analiza metryk chrztów z tamtejszej parafii (zachowanych od 1592 r.), które opublikował Marek Górny. M. Górny, Metryki chrztów z parafii smoguleckiej. Cz. 1. Lata 1592-1618, „Genealogia”, 5, 1995, s. 105-140. Por. tenże, Metryki chrztów z parafii smoguleckiej. Cz. 2. Lata 1619-1652, „Genealogia”, 6, 1995, s. 89-132. W źródle tym istnieje wyraźne odróżnienie miasta (oppidum) Smogulec od wsi (villa) Smogulec. Bardziej istotny jest jednak fakt, że w zapisach z przełomu XVI i XVII w. w Smogulcu pojawiają się rzemieślnicy nie tylko takich specjalności, jak szewc, krawiec, kowal czy cieśla, które spotykamy także we wsiach, ale również innych zawodów, jak kuśnierz, płóciennik, bednarz, piekarz, murarz i piwowar, które występowały z reguły w ośrodkach miejskich. Istnienie kilkunastu warsztatów różnych specjalności (z zapisów wynika, że w tym czasie w Smogulcu działało 3 krawców, 2 szewców i 2 płócienników oraz po jednym rzemieślniku z wymienionych wyżej) jest typowe dla miasteczek wielkopolskich w tym okresie i wskazuje na możność zaspokajania potrzeb własnych ośrodka i jego rynku lokalnego. J. Wiesiołowski, Sieć miejska w Wielkopolsce w XIII-XVI w. Przestrzeń i spoteczeństwo, „Kwartalnik Historii Kultury Materialnej", 28 (3), 1980, s. 392-393. Zdaniem Andrzeja Wędzkiego zarówno Czeszewo, Srebrna Góra i Stępuchowo, jak i Smogulec utracity swoje funkcje miejskie między 2. poł. XV a 1. poł. XVII w. A. Wędzki, Rozwój sieci, s. 143; L. Polaszewski, Własność feudalna, s. 50.

49 M. Bogucka, H. Samsonowicz, Dzieje miast i mieszczaństwa w Polsce przedrozbiorowej, Wroctaw 1986, s. 337.

50 Miasta powyżej 5000 mieszkańców oznaczamy jako miasta duże. AHP: Mazowsze, cz. 2, s. 83-84. 
Spośród miast powiatu kcyńskiego jedynie Żnin określany bywał w źródłach jako civitas, a ustawa pogłównego z 1520 r. zalicza go do miast drugiej kategorii (civitates et oppida secundi ordinis $)^{51}$. W porównaniu z innymi miastami Wielkopolski, jak Poznań, Kościan czy Gniezno, określić go można jako miasto średniej wielkości. Potencjałem rzemiosła i liczbą warsztatów Żnin niemal dorównywał Kaliszowi, a przewyższał zapewne Koło - siedzibę sejmiku generalnego województw Wielkopolski ${ }^{2}$. Rejestr poborowy z 1591 r. notuje w Żninie 207 domów i chałup w samym mieście oraz 89 chałup na przedmieściach ${ }^{53}$. Na tej podstawie liczbę jego mieszkańców (z przedmieściami) szacować można w końcu XVI w. nawet na ok. $2500^{54}$. Drugie miejsce pod tym względem zajmował w owym czasie w powiecie kcyńskim Wągrowiec. W 1591 r. zanotowano tu 183 domy i chałupy (z czego 127 w mieście). Według inwentarza majętności i dochodów opactwa wągrowieckiego z 1611 r. miasto miało aż 303

51 LBG I, s. 143; ASK I 4, k. 232; Corpus iuris Polonici, vol. 3: Annos 1506-1522 continentis, wyd. 0. Balzer, Cracoviae 1906 s. 598. Znaczenie określeń „civitas” i „oppidum” zob. Z. Kulejewska-Topolska, Oznaczenia i klasyfikacje miast w dawnej Polsce (XVI-XVIII w.), „Czasopismo Prawno-Historyczne”, 8 (2), 1956 s. 256-258. W ustawie z 1590 r. o wysokości poboru m. in. z miast sformułowanie "secundi ordinis" poprzedzono polskim "miasta średnie". Tamże, s. 263.

52 A. Klonder, Pałuki, s. 51.

53 ASK I 4, k. 789-789v. Skład zawodowy mieszkańców Żnina (wraz z danymi liczbowymi) na podstawie rejestrów poborowych zestawił dla lat 1564-1634 Jerzy Kądziołka. J. Kądziołka, Żin po lokacji (1263-1654), w: Żnin. 700 lat dziejów miasta, red. J. Topolski, W. Sobisiak, Bydgoszcz 1965, s. 55-56, tab. 1-2.

54 W obliczeniach przyjęto przelicznik 9 osób na jeden dom, tak samo jak w kolejnych tomach z serii „Atlasu historycznego Polski”. Zob. AHP: Województwo krakowskie, cz. 2: Komentarz, indeksy, s. 71. Wizytacja z 1616 r. notuje w Zninie 318 domów zasiedlonych oraz 35 pustych. J. Kądziołka, Żnin po lokacji, s. 54. Badacz ten przyjmuje, że na przetomie XVI i XVII w. miejscowość ta mogła liczyć 2000-2500 osób. Tamże, s. 55-57. Podobnie szacuje ówczesną liczbę jego mieszkańców Andrzej Klonder. A. Klonder, Pałuki, s. 51, 63. Jacek Wiesiołowsk zalicza zaś Żnin w tym okresie do miast dużych, jako podstawę klasyfikacji przyjmując liczbę rzemieślników. J. Wiesiołowski, Sieć miejska, mapa 5: Hierarchia sieci miejskiej w Wielkopolsce ok. 1580 r. Na temat liczby mieszkańców i domów w Żninie w XVI i 1. poł. XVII w. zob. też: S. Truchim, Żnin za czasów królów elekcyjnych, w: Historia powiatu żnińskiego, red. S. Truchim, Poznań 1928, s. 139 n.; R. Witkowski, Czasy nowożytne (od początku XVI w. do 1815 r.), w: Żnin. 750 lat dziejów miasta, t. 1, red. T. Janicki, Żnin 2013, s. 83-139.

55 ASK I 4, k. 790v; A. Wyrwa, Powstanie, organizacja i charakter cysterskiego ośrodka miejskiego w Wagrowcu, w: Klasztor w mieście średniowiecznym i nowożytnym, red. M. Derwich, A. Pobóg- domy i 90 pustych placów 55 . Stąd oceniać można, że w końcu XVI stulecia zamieszkiwało je w przybliżeniu 1500-1600 osób. W $1591 \mathrm{r}$. poborca podatkowy nie zanotował niestety liczby domów w Kcyni, podając tylko sumę płaconego podatku. Zapisał natomiast rodzaj i liczbę kcyńskich rzemieślników (86) oraz posiadanych przez miasto łanów (ponad 48). Na tej podstawie ówczesną liczbę mieszkańców stolicy powiatu szacować można na ok. $1000^{56}$. Populację Łabiszyna w końcu XVI w. oceniać można w przybliżeniu na 700 osób, w 1591 r. istniało tam bowiem 81 domów i chałup ${ }^{57}$. Ludność Chodzieży liczyła w tym czasie ok. 500 osób, a pobliskiego Margonina - ok. 350. Według rejestru poborowego w 1591 r. Chodziez zapłaciła podatek od 57 domów i chałup, a Margonin od 42. W 1. poł. XVII w. oba te miasta znacznie się rozwinęły; rejestr pogłównego z 1635 r. notuje aż 194 domy w Chodzieży i 84 w Margoninie ${ }^{58}$. Podobną liczbę mieszkańców - po ok. 300 osób - miały w tym czasie Rynarzewo i Barcin;

-Lenartowicz, Wrocław-0pole 2000, s. 176. Zob. też Z. Boras, W dobie szlacheckiej Rzeczpospolitej, w: Dzieje Wągrowca, red. E. Makowski, Poznań 1994, s. 57-90.

56 0d domów miasto miało zapłacić 7 grzywien. ASK I 4, k. 791. Na podstawie samej sumy płaconego podatku nie można wnioskować o liczbie domów, ponieważ kwota poboru zależała od lokalizacji budynku (najwyżej opodatkowane były domy przyrynkowe), oceny jego wartości oraz kategorii wielkości, do której należało dane miasto. Por. Uniwersał poborowy na sejmie walnym koronnym warszawskim w roku 1591 uchwalony, w: Volumina constitutionum, t. 2: 1550-1609, vol. 2: 1587-1609, przyg. do druku S. Grodziski, Warszawa 2008, s. 183-184. W 1591 r. w Kcyni zanotowano ponadto 12 komorników. W obliczeniach przyjęto wskaźnik 10 osób na łan (dobra królewskie), 5 osób w przypadku rodzin rzemieślniczych, a 4 dla rodzin komorniczych, podobnie jak w AHP Województwo sieradzkie, cz. 2, s. 54. Liczbę domów w Kcyni znamy ze źródeł XVII-wiecznych. Rejestr podymnego z 1635 r. notuje tu 120 domów. F. Mincer, Dzieje Kcyni do 1772 r., w: Dzieje Kcyni i okolic, red. W. Jastrzębski, Kcynia 1993, s. 49. W przeprowadzonej po potopie lustracji dóbr królewskich zapisano zaś, że w Kcyni było niegdyś 140 domów (w tym 20 żydowskich), a zostało 55. Lustracja województw wielkopolskich i kujawskich 1659-1665, wyd. C. Ohryzko-Włodarska, cz. 1, Wrocław-Warszawa 1978, s. 191.

57 SK I 4, k. 789v. Na pocz. XVII w. miasto przeżyło duży pożar, a liczba jego domów spadła. W 1635 r. zanotowano ich tam zaledwie 28. F. Mincer, Dzieje Kcyni, s. 49

58 ASK I 4, k. 788v, 791v; F. Mincer, Dzieje Kcyni, s. 49. Podobne szacunki - 500-600 osób dla Chodzieży (wliczając w to ok. stuosobową ludność żydowską) i ok. 300 dla Margonina - podaje Stefan Chmielewski. S. Chmielewski, Od lokacji miasta, s. 47-48. Szacunki proponowane przez Danutę Konieczkę-Śliwinską - 130 mieszkańców Margonina w 2. poł. XVI w. - są zaniżone. D. Konieczka-Śliwińska, Dzieje Margonina w dobie staropolskiej, w: Dzieje Margonina, red. K. Rzepa, Poznań 2002, s. 32-33. 
w 1591 r. zapłaciły one podatek odpowiednio od 38 i 36 domów. W ciągu następnych czterdziestu lat liczba domów w Rynarzewie podwoiła się, w Barcinie zaś wzrosła aż trzykrotnie. Populacja Żernik utrzymywała się natomiast na niemal niezmienionym poziomie, oscylując wokół 250 osób; w 1591 r. zanotowano tu 32 domy i chałupy, a w roku 1635 o trzy więcej9. Na ok. 150 osób szacować można w tym czasie liczbę mieszkańców Szubina; według zapisu z 1591 r. było tu zaledwie 19 domów, a w następnych dziesięcioleciach liczba ta wzrosła kilkakrotnie - do $72 \mathrm{w} 1635$ r. ${ }^{60}$ Oszacowanie przybliżonej liczby mieszkańców Łekna w końcu XVI w. napotyka na trudności. W rejestrze z 1591 r. zanotowano istnienie jedynie 25 domów na przedmieściach; brak zaś informacji o domach w mieście ${ }^{61}$. Według przyjętych wskaźników na przedmieściach mieszkałoby zatem ok. 200 osób, co pozwala przypuszczać, że populacja samego miasta była co najmniej równa. W literaturze przyjmuje się, że ok. 1500 r. Łekno zaliczało się do miast III grupy wielkości, tj. do 1000 mieszkańców ${ }^{62}$. W roku 1635 zanotowano tu 85 domów, a więc żyło tu wtedy ok. 750 osób $^{63}$. Zaludnienie Smogulca i Gołańczy w omawianym czasie możemy oceniać jedynie na podstawie rejestrów poborowych, w których obie miejscowości traktowane są jako wsie. Według tych zapisów liczbę mieszkańców obu miasteczek szacować możemy w przybliżeniu na 120-140 osób, przy czym Smogulec był, jak się zdaje, bardziej ludny niż Gołańcza ${ }^{64}$.

59 ASK I 4, k. 790, 791v. Rejestr pogtównego z 1635 r. notuje w Rynarzewie 79 domów, a w Barcinie 139. M. Mincer, Dzieje Kcyni, s. 49.

60 ASK I 4, k. 791; B. Janiszewska-Mincerowa, F. Mincer, W okresie staropolskim (XIV w.-1773), w: Dzieje Szubina, red. M. Biskup, Warszawa-Poznań 1974, s. 41-42.

${ }^{61}$ ASK I 4, K. 788v

62 Do tej samej grupy zaliczone są z powiatu kcyńskiego: Kcynia, Łabiszyn, Margonin i Wągrowiec. M. Bogucka, H. Samsonowicz, Dzieje miast, s. 115 i n.

63 B. Janiszewska-Mincerowa, F. Mincer, W okresie staropolskim, s. 42. W pobliskim Wagrowcu wzrost liczby domów między 1591 a 1635 r. wyniósł ok. $25 \%$.

64 ASK I 4, 220v, 230, 336v, 349v, 359v, 371v, 542, 552, 581, 590v $736 v, 745,777 v, 785 v$; ASK I 13, k. 198, 207v. Na temat stosowanych przeliczników zob. przyp. 56 oraz AHP: Województwo krakowskie, cz. 2, s. 76 .
W powiecie kcyńskim przeważały małe osady wiejskie $\mathrm{z}$ areałem nieprzekraczającym 10 łanów ziemi uprawnej bez gruntów folwarcznych. Tylko piętnaście wsi (a więc niecałe 6\%) miało 20 lub więcej łanów, jednak stan ich posiadania nie przekraczał 30 łanów. Były to: Morakowo i Czerlenin (parafia Czeszewo), Dziewierzewo (parafia własna), Januszkowo i Murczyno (parafia Góra Arcybiskupia), Gorzyce (parafia własna), Juncewo (dawniej Janczewo, parafia własna), Siedlec (parafia Juncewo), Grocholino (parafia Kcynia), Łukowo (parafia Łekno), Panigrodz (parafia własna), Stołężyn (dawniej Stołyżyno, parafia Panigrodz), Jaroszewo i Gogółkowo (parafia Żnin). Wyjątkiem była wieś Źórawia (parafia Kcynia), która miała 40 łanów $^{65}$. Miasta również posiadały ziemię uprawna, jednak w omawianym okresie były to w większości także majątki kilkułanowe. Powyżej 10 łanów miały: Gołańcza - 16, Wągrowiec-18, Żnin - 24 i Kcynia - $48^{66}$.

$\mathrm{Na}$ podstawie rejestrów poborowych możemy w przybliżeniu oszacować pewne minimum wielkości areału uprawianego na danym terenie. Zestawienie danych $\mathrm{z}$ siedmiu rejestrów z lat 1565-1618 dla powiatu kcyńskiego pozwala stwierdzić kilka kwestii. Suma łanów uprawnych uwzględnionych w rejestrach wynosiła w 2. poł. XVI w. ok. 2000, wahając się od 2170 w 1565 r. do 1989 w 1582 r. W okresie tym zauważyć można wyraźną tendencję spadkową aż do poziomu 1818,5 łana w $1591 \mathrm{r}$. i 1679,5 łana w 1618 r. Spadła liczba łanów kmiecych oraz należących do sołtysa, natomiast niemal 2,5-krotnie wzrosła liczba łanów pustych: od $100 \mathrm{w} 1565$ r. do $247 \mathrm{w} 1582$ r. $^{67}$

65 W obliczeniach wzięto pod uwage wszystkie kategorie zadeklarowanych łanów, a także łany sołtysie i puste. Uwzględniono jednak tylko te osady, których areał równy był 20 łanom lub przekraczał je przez większość okresu objętego analizowanymi rejestrami poborowymi.

66 Trzy miasta - Barcin, Łabiszyn i Rynarzewo - w ogóle nie miały ziemi uprawnej. Jak twierdzi Danuta Konieczka-Śliwińska, posiadana przez miasto liczba łanów nie była w żadnym wypadku miarą wielkości jego powierzchni, a jedynie uposażeniem w ziemię, jakie dostawało zwykle w momencie lokacji. D. Konieczka-Śliwińska, Dzieje Margonina, s. 28. Dane dla 1. poł. XVII w. zestawia Paweł Klint. P. Klint, Szlachecki obrót, s. 28-29.

67 Spadek liczby łanów sołtysich jest największy między rokiem 1565 (84,5 łana) a $1578(57,5)$. Następnie do końca XVI w. ich liczba jest prawie niezmienna $(55,5-58,5)$ i dopiero rejestr z lat $1618-1620$ notuje jej spadek do 46,5 tana. 
$\mathrm{Na}$ pocz. XVII w. obserwujemy dalsze szybkie pogłębianie się tej tendencji - w 1618 r. odnotowano niemal 300 łanów pustych ${ }^{68}$. Zjawiska te mają związek z coraz bardziej intensywną akcją tworzenia i powiększania folwarków szlacheckich, polegającą m.in. na włączaniu do nich pustek uprawianych wcześniej przez kmieci ${ }^{69}$. Przyjmuje się, że w omawianym czasie 1 łan odpowiadał w Wielkopolsce w przybliżeniu 16,8 ha $^{70}$. Powierzchnia ziemi uprawnej uwzględnionej w rejestrach poborowych z 2. poł. XVI w. (a więc bez areału folwarcznego) wynosiła zatem w powiecie kcyńskim ok. 33600 ha $(336$ km²), czyli niewiele ponad $14 \%$ całego obszaru powiatu. Dla powiatu kcyńskiego dotychczas brak jest szczegółowych badań określających liczbę folwarków i wielkość powierzchni zajmowanej przez nie w owym czasie ${ }^{71}$. Marcin Kamler, analizując i uśredniając dane dla całej zachodniej Wielkopolski, ustalił, że w latach 1580-1655 na każde 100 łanów kmiecych przypadało ok. 125 folwarcznych $^{72}$. Całkowitą wielkość ziemi użytkowej na terenie powiatu kcyńskiego

68 W powyższej analizie nie wzięliśmy pod uwagę danych z 1577 r., kiedy zanotowano w sumie ok. 400 tanów mniej niż w innych rejestrach. Przyczyn takiego stanu rzeczy może być wiele i wobec braku danych z całości dostępnych źródeł nie można o tym rozstrzygać w jednoznaczny sposób. Przypuszczać można jednak, że miało to związek z odnotowanym w źródłach gradobiciem, które dotknęło wówczas część powiatu kcyńskiego, niszcząc zasiewy. ASK I 13, k. 197, 208v. Ostrożnie trzeba traktować także rejestr z $1591 \mathrm{r}$., bowiem nie odnotowano w nim danych dla 15 osad.

69 S. Orsini-Rosenberg, Rozwój i geneza folwarku pańszczyźnianego w dobrach katedry gnieźnieńskiej w XVI w., Poznań 1925; A. Wyczański, Studia nad folwarkiem szlacheckim w Polsce w latach 1500-1580 Warszawa 1960, s. 37-55; J. Topolski, Przyczyny powstania i rozwój folwarku pańszczyźnianego, w: Dzieje Wielkopolski, t. 1: Do roku 1793, red. J. Topolski, Poznań 1969, s. 445-459; P. Szafran, Osadnictwo historycznej Krajny w XVI-XVIII w. Gdańsk 1961, s. 49-73.

70 Wielkość łanu używanego w Koronie nie była jednakowa i wykazywała spore różnice między zachodnią i wschodnią częścią państwa. Również w samej Wielkopolsce nie była stała i według różnych szacunków wynosita od 14,75 do 17,5 ha. K. Sochaniewicz, Slad, pótśledzie, kwarta i kęs roli. (Ze studjów nad miarami w Wielkopolsce w XVI i XVII w.), „Roczniki Historyczne”, 5 (1), 1929, s. 90-102; M. Kamler, Łan, hasto w: Encyklopedia historii gospodarczej Polski do $1945 \mathrm{r}$. red. A. Mączak, Warszawa 1981, t. 1, s. 446. Obecnie przyjmuje się, że na terenie Wielkopolski przeważał łan liczący 16,8 ha. J. Topolski, Gospodarstwo wiejskie w dobrach arcybiskupstwa gnieźnieńskiego od XVI do XVII w., Poznań 1958, s. 381; J. Karczewska, Średniowieczne miary powierzchni ziemi w Wielkopolsce i na Kujawach w świetle źródet sądowych, w: Człowiek wobec miar, s. 143-151; taż, Własność szlachecka na pograniczu wielkopolsko-kujawskim w pierwszej połowie XV wieku, Kraków 2010, s. 388-393. Zob. też w 2. poł. XVI stulecia, wliczając tu oprócz folwarków także łąki i pastwiska, można zatem z dużą ostrożnością szacować jedynie na ok. $30 \%$ całej powierzchni powiatu ${ }^{73}$.

Dzięki źródłom znamy rozmieszczenie, typ oraz wielkość młynów wodnych i wietrznych. W XVI w. w Polsce konstruowano głównie dwa typy młynów wodnych: podsiębierne (walne) i nasiębierne (korzeczne). Koła młyna walnego poruszane były prądem wody napierającym od dołu na jego łopatki, z wykorzystaniem energii kinetycznej wody. Młyn tego rodzaju był stosunkowo łatwy w konstrukcji, wymagał jednak cieku o bystrym nurcie. Do ich budowy wykorzystywane były naturalne warunki terenowe. Jeśli prąd wody był silny, młyny walne miały znaczną moc. Koła młynów korzecznych obracały się natomiast dzięki sile wody spadającej $\mathrm{z}$ góry, dlatego też miały większą wydajność. Ich konstrukcja była jednak trudniejsza do wykonania, bowiem wymagała doprowadzenia i spiętrzenia wody poprzez budowę kanałów, tam lub

A. Dunin-Wąsowicz, Pomiary gruntu w Koronie w XVI-XVIII wieku: próba ustalenia wielkości ról chłopskich na ziemiach polskich, Warszawa 1994

71 Według ogólnych badań Andrzeja Wyczańskiego (uzyskanych po analizie 7 przykładów) w latach 1551-1580 w powiecie kcyńskim średni areał folwarku wynosił 3,8 łana. A. Wyczański, Studia nad folwarkiem, s. 89.

72 Marcin Kamler przeanalizował tylko folwarki szlacheckie. M. Kamler, Folwark szlachecki w Wielkopolsce w latach 1580-1655, Warszawa 1976, s. 12-32, 160-163. Analizując porównawczo należące do arcybiskupstwa gnieźnieńskiego folwarki wielkopolskie, ustalił, że w 1. poł. XVII w. współczynnik ufolwarcznienia w tych dobrach był znacznie niższy - na 100 łanów kmiecych przypadały tu jedynie 43 łany folwarczne. Na temat średniej wielkości folwarków zob. tenże, Areat folwarku szlacheckiego w Wielkopolsce Wschodniej 15801655, „Przegląd Historyczny”, 62 (2), 1971, s. 177-196. Folwarki we wsiach szlacheckich (w liczbie 43) istniejące w powiecie kcyńskim w 1. poł. XVII w. zestawia Paweł Klint. P. Klint, Szlachecki obrót, s. 40, przyp. 141. Badacz ten twierdzi jednak, że „folwarków we wsiach było znacznie więcej [...]. Istnienie folwarku przynajmniej w co drugiej wsi wymuszała struktura majątkowa pałuckiej szlachty [...]". Tamże, s. 40 .

73 Na temat dotychczasowych ustaleń w tej kwestii oraz o próbie nowego oszacowania powierzchni zajmowanej przez grunty użytkowe, lasy i nieużytki zob. T. Gidaszewski i in., Transformations of the Natural Landscapes of the Middle Notec Region from the Tenth to the Sixteenth Century, w: Landscapes and Societies in Medieval Europe East of the Elbe. Interactions between Environmental Settings and Cultural Transformations, ed. S. Rossignol i in., Toronto 2013 (Papers in Mediaeval Studies, 23), s. 245-273. Por. też ustalenia Arkadiusza Borka. A. Borek, Powiat kcyński. 
sztucznych stawów ${ }^{74}$. W powiecie kcyńskim w 2. poł. XVI w. funkcjonowało blisko 40 mtynów wodnych. Spadek tej liczby widoczny jest dopiero na pocz. XVII w. ${ }^{75}$ Młyny korzeczne stanowity początkowo $2 / 3$ wszystkich odnotowanych; potem obserwujemy zmniejszanie się ich liczby, przy stałej ilości młynów walnych. Analiza rozmieszczenia młynów w powiecie kcyńskim pozwala stwierdzić, że walne znajdowały się głównie na największych rzekach tego regionu - na Noteci w Łabiszynie, Barcinie oraz na północ od osady Gromadno (trzykołowy młyn Gromadzki, parafia Smogulec), gdyż tylko tam był odpowiednio silny nurt, a zarazem dobry dostęp do rzeki (brak bagien); na Gąsawie we wsi Słupy oraz na Wełnie przy Wągrowcu $^{76}$, Mieścisku, Żernikach i Janowcu (np. młyn Dziekczyn należący do wsi Wybranowo ${ }^{77}$ ), gdzie wykorzystano znaczny spadek terenu. Młyn walny zlokalizowany był również we wsi Jaroszewo, zapewne w miejscu, gdzie niewielki strumień spływa ze skarpy do Jeziora Żnińskiego, oraz w Żninie (między Jeziorem Żnińskim Dużym a Małym). Liczba kół młyńskich, czyli wielkość młynów, ma związek z charakterem osady. Największe młyny budowano w miastach, co jest oczywiste ze względu na większe zapotrzebowanie na mąkę.

Tereny północnej Wielkopolski należą do regionów o korzystnych warunkach wietrznych - średnia siła wiatru wynosi tu $4,5-5 \mathrm{~m} / \mathrm{s}^{78}$. Stąd też na wyniesionych, odsłoniętych pagórkowatych terenach, tam gdzie brak było odpowiednich warunków hydrograficznych, już od $\mathrm{XIV}$ w. konstruowano wiatraki ${ }^{79}$. Stosowano

74 H. Samsonowicz, Rzemiosto wiejskie w Polsce XIV-XVI w., Warszawa 1954, s. 122-126; M. Frančić, Technika młynów wodnych w Polsce w XVI i XVII w., ,Kwartalnik Historii Kultury Materialnej”, 2 (1-2), 1954, s. 79-103.

75 Liczba młynów wodnych w powiecie kcyńskim w tym czasie wahała się nieznacznie od 39 w 1565 r. do 36 w 1582 r. Rejestr z 1591 r. odnotował jedynie 31 młynów, podobnie ten z lat 1618-1620.

76 Zob. M. Moeglich, Mtyny wagrowieckie w „czasach cysterskich”. Zarys problemu, w: Wangrovieciana. Studia et Fontes. Wagrowieckie studia muzealne, Wagrowiec 2013, s. 11-25.

77 Teki Dworzaczka: księgi grodzkie i ziemskie nakielskie, cz. 2: 167 (nr 222), 1619 r.

78 http://www.uwm.edu.pl/kolektory/silownie/obliczenia.html, dostęp: 15 lipca 2015. Jest to średnia prędkość wiatru na wysokości $20 \mathrm{~m}$ n.p.m. wówczas tzw. wiatraki kozłowe (koźlaki), drewniane, obracające się w całości przy nastawieniu na kierunek wiatru. W ciągu 120-150 wietrznych dni w roku wiatrak kozłowy był w stanie zemleć 60-80 ton ziarna. Typ ten był właściwie jedynym na ziemiach polskich aż do XVIII w., kiedy zaczęły się pojawiać tzw. holendry o większej mocy, w których obracała się tylko głowica ze skrzydłami ${ }^{80}$. Liczba wiatraków w powiecie kcyńskim w 2 . poł. XVI w. wahała się od 52 do 56, zaś na pocz. XVII w. spadła do 44. Skoncentrowane były one w środkowej części regionu o najmniejszym zalesieniu. Nie występowały zaś w ogóle na jego obrzeżach. Zwykle we wsi stawiano jeden wiatrak, ale zdarzały się osady z dwoma - jest to jednak liczba maksymalna ${ }^{81}$.

W powiecie kcyńskim zdecydowanie dominowała własność szlachecka. Szacuje się, że w rękach szlachty znajdowało się ok. $80 \%$ posiadłości. Około $18 \%$ stanowiła własność kościelna, zaś tylko ok. $1 \%$ dóbr należało do króla, a $1 \%$ stanowił własność mieszaną? Brak było natomiast własności miejskiej.

Jak już wyżej wspomniano, własność szlachecką stanowiło $\mathrm{w}$ powiecie kcyńskim 10 miast. Wśród wsi szlacheckich znacząco przeważały jednodziałowe. Wsi kilkudziałowych było zaledwie ok. 40, przy czym znakomita ich większość podzielona była między dwóch właścicieli ${ }^{83}$. Udział szlachty zagrodowej we

79 Pierwszy wiatrak w Wielkopolsce odnotowano w źródłach w $1303 \mathrm{r}$. J. Święch, Wiatraki. Młynarstwo wietrzne na Kujawach, Włocławek 2001, s. 42-45.

80 J. Święch, Wiatraki, s. 51-81, 119-120, 128. Przegląd polskiej literatury i stanu badań nad wiatrakami daje Zbigniew Chodyła. Z. Chodyła, Les moulins à vent en Pologne, w: I mulini nell'Europa medievale. Atti del Convegno di San Quirino d'Orcia 21-23 settembre 2000, a cura di P. Galetti, P. Racine, Bologna 2003, s. 175-202.

81 Po dwa wiatraki funkcjonowały we wsiach: Czeszewo, Cerekwica, Żórawia, Niemczynek (dawniej Memczynko), Świątkowo (dawniej Świętkowo), Bożejewice.

82 A. Borek, Powiat kcyński; L. Polaszewski, Własność feudalna, s. 64 , tab. 8. Do osad królewskich w powiecie kcyńskim Leon Polaszewski zalicza Brzekiniec i Podstolice (s. 31 i mapa), które w omawianym tu okresie znajdowały się w granicach województwa poznańskiego, stąd też jego szacunki, że własność królewska zajmowała w powiecie kcyńskim 2,5\%, należy jeszcze obniżyć.

83 L. Polaszewski, Własność feudalna, s. 71, tab. 15. Jedyną wsią, która przez cały omawiany okres miała cztery działy podatkowe, było Dziewierzewo. 


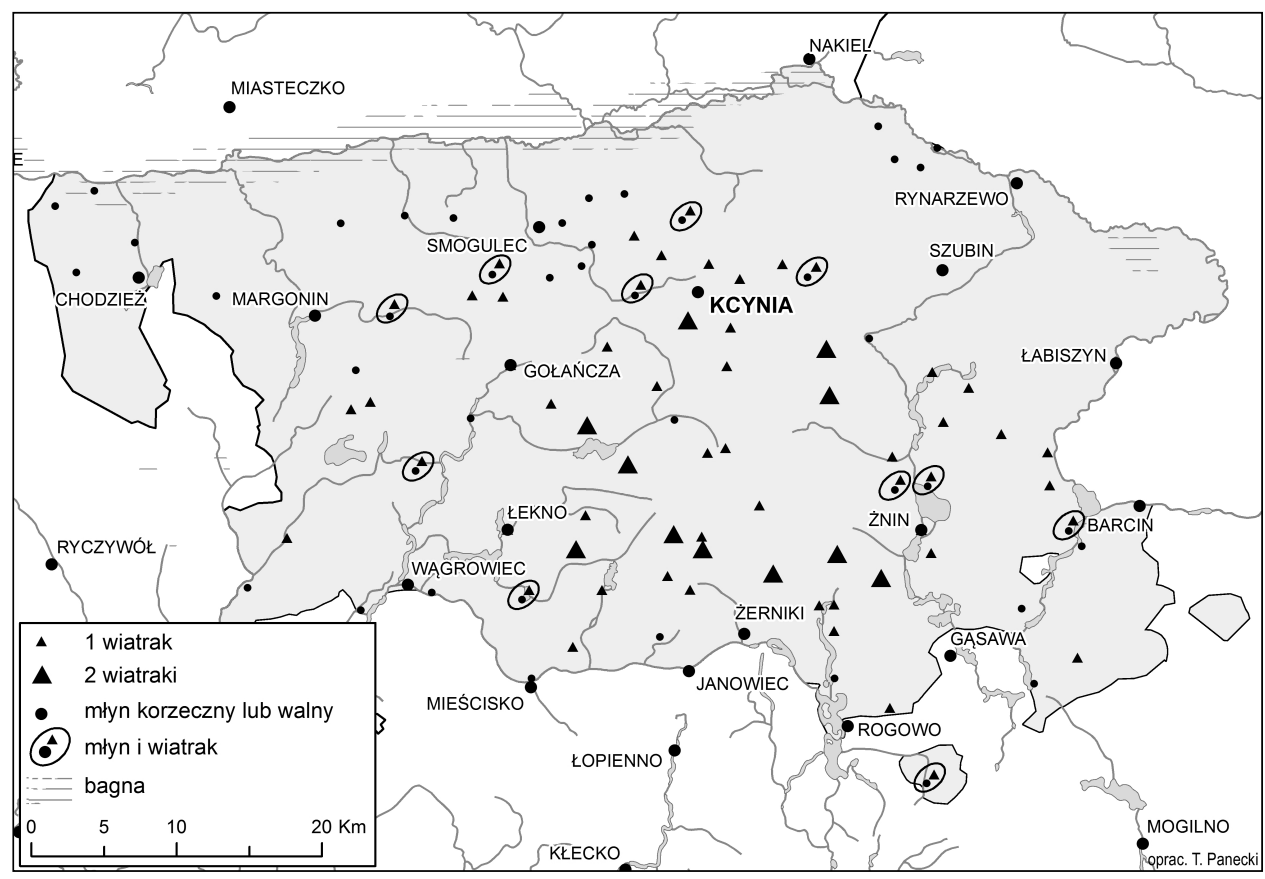

Mapa 4. Młyny wodne i wiatraki w powiecie kcyńskim w 2. pot. XVI w.

własności był $\mathrm{w}$ powiecie kcyńskim znikomy i wynosił zaledwie ok. $4 \%$ - najmniej w całym województwie kaliskim. Według obliczeń Leona Polaszewskiego szlachta zagrodowa zamieszkiwała na tym terenie w dziewięciu wsiach, z czego tylko trzy zasiedlone były przez nią w całości ${ }^{84}$. Większa własność koncentrowała się w omawianym okresie w rękach:

84 Tamże, s. 53-54, tab. 16-17, s. 72, tab. 18, s. 73. W części opisowej swej pracy Leon Polaszewski nie podaje jednak, w których dokładnie wsiach mieszkała szlachta zagrodowa. Nie można się tego dowiedzieć także z zestawienia wsi szlacheckich powiatu kcyńskiego. Tamże, s. 184-194. Autor odnotował szlachtę zagrodową tylko w sześciu wsiach: Kościenkowo, Laskownica Wielka i Mała, Odołkowice, Puzdrowiec i Rozpętek. Ze spisu nie wynika, czy dana wieś zamieszkiwana była przez nią w całości, czy w cześci. W zachowanych dla powiatu kcyńskiego rejestrach poborowych wykaz szlachty płacącej podatek od swych gruntów spisany według zamieszkiwanych wsi widnieje tylko w latach 1564 i 1565 (pozostałe rejestry notuja jedynie same nazwiska). Według tych zapisów szlachta płacąca od swych tanów i zagrodników zamieszkiwała 7 wsi: Bożejewice, Puzdrowiec, Wybranowo, Zalesie, Rozpętek, Włoszynowo i Kościenkowo. ASK I 4, k. 234v, 584v. Na temat struktury własnościowej szlachty pałuckiej w omawianym okresie zob. też A. Klonder, Pałuki, s. 14-17.

85 S. Leitgeber, Potuliccy, Londyn 1990, s. 7-13, 17-29, 33-72 i mapa 2: Dobra Potulickich w Wielkopolsce.

86 B. Janiszewska-Mincerowa, F. Mincer, Wokresie staropolskim, s. 31-40; A. Klonder, Pałuki, s. 29-34.

87 A. Wędzki, Okres staropolski, s. 42-44.
Potulickich (dobra chodzieskie) ${ }^{85}$; Czarnkowskich (dobra szubińskie) ${ }^{86}$; Grudzińskich, a następnie Czarnotulskich (dobra gołanieckie) ${ }^{87}$; Krotoskich (dobra barcińskie) ${ }^{88}$; Rynarzewskich (dobra rynarzewskie); Latalskich (dobra łabiszyńskie) ${ }^{89}$; Margońskich (dobra margonińskie ${ }^{90}$; Grzymułtowskich (dobra stępuchowskie) i Smoguleckich ${ }^{91}$.

88 J. Krzyś, C. Cieślak, Szkice z przesztości Barcina, Barcin 2009, s. 21.

89 I. Kaniewska, Latalski Janusz, hasło w: Polski Stownik Biograficzny [dalej: PSB], t. 16, Wrocław 1971, s. 563-564.

90 Margonin i pięć osad (osiadłe: Margońska Wieś i Wiśniewo oraz puste: Biekowo, Garbowo i Gitkowice) przeszły następnie w ręce Czarnkowskich, ci zaś sprzedali je w 1567 r. późniejszemu podskarbiemu koronnemu i kasztelanowi śremskiemu Jakubowi Rokossowskiemu. Po jego śmierci dobra te objął jego syn Jan, który w 1591 r. sprzedał Margonin z przyległościami sufraganowi włocławskiemu Janowi Rozdrażewskiemu. Teki Dworzaczka: księgi grodzkie i ziemskie poznańskie, rezygnacje, XVI w.: 7974, 8523 (nr 1396), 10201, 10202, 10226 (nr 1397), 13500 (nr 1400); L. Polaszewski, Własność feudalna, s. 184-194. Por.: H. Kowalska, Rokossowski Jakub h. Glaubicz, hasto w: PSB, t. 31, Wrocław 1988-1989, s. 537; W. Kujawski, Rozdrażewski (Rozrażewski) Jan h. Doliwa, hasło w: PSB, t. 32, Wrocław 1989-1991, s. 373-374. Na temat kolejnych właścicieli Margonina zob. D. Konieczka-Śliwińska, Dzieje Margonina, s. 48-51.

${ }_{11}$ S. Leitgeber, Smoguleccy herbu Grzymała. Dzieje rodziny od XVI do XVIII w., „Genealogia”, 6, 1995, s. 27-52. 
Posiadłości duchownych zajmowały przede wszystkim południową część powiatu kcyńskiego. Koncentrowały się one głównie w rękach dwóch instytucji kościelnych: arcybiskupstwa gnieźnieńskiego i opactwa cysterskiego w Wągrowcu. Do dóbr stołowych arcybiskupa gnieźnieńskiego wchodził klucz żniński, do którego w powiecie kcyńskim należało miasto Żnin, 20 całych wsi skupionych wokół niego (głównie w czterech parafiach: Żnin, Gorzyce, Góra Arcybiskupia i Wenecja) oraz pół wsi Ryszewo (parafia Ryszewko) ${ }^{92}$. Własnością opactwa cystersów w Wągrowcu było miasto Wągrowiec oraz 20 wsi z terenu powiatu kcyńskiego $^{93}$. Do kapituły gnieźnieńskiej należały cztery wsie: Słabomierz w parafii Gorzyce) oraz Szczepanowo, Szczepankowo i Wójcin (dawniej Wojucino) w parafii Szczepanowo, a także folwark Ujazd w parafii Kcynia ${ }^{94}$. W skład uposażenia sufragana gnieźnieńskiego wchodziło probostwo w Żninie, do którego przynależały wsie Rydlewo i Skarbienice ${ }^{95}$. Pozostałe wsie stanowiące uposażenie kościołów parafialnych z dekanatu łekneńskiego i żnińskiego to: Gąbin (własność parafii Słupy), Graboszewo (parafia Dziewierzewo), Krzepiszyn (parafia Kcynia), Micharzewo (parafia Łekno) oraz Wieszki (parafia Szubin ${ }^{96}$. Po jednej osadzie należało do klasztoru kanoników regularnych w Trzemesznie (Ryszewko) oraz do klasztoru bożogrobców w Gnieźnie (Grochowiska Księże) ${ }^{97}$.

Powiat kcyński miał najmniejszą liczbę królewszczyzn w całym województwie, a znajdowały się one w północnej i środkowej jego części. W sumie było to jedynie pięć osad przynależących do dwóch różnych starostw: Kcynia (wówczas w zastawie) - siedziba starostwa niegrodowego ${ }^{98}$ wraz z przedmieściami (Kcyńskim Wójtostwem i Grabowem), oraz Polichno (dawniej Polikno) i Rozważyn w parafii Samoklęski - wchodzące w skład starostwa nakielskiego. $\mathrm{Na}$ terenie powiatu kcyńskiego w posiadaniu starostwa nakielskiego były również nadnoteckie bagna i lasy.

Sieć osadnicza powiatu kcyńskiego - zdeterminowana w dużym stopniu przez występowanie specyficznych warunków naturalnych: duże zalesienie (zwłaszcza na terenach nadgranicznych) oraz sieć hydrograficzną nie uległa poważniejszym zmianom przez kolejne kilkadziesiąt lat. Zmiany w krajobrazie naturalnym i osadniczym tego obszaru przyniósł dopiero koniec XVII w., kiedy zaczęto osuszać i zasiedlać zabagnione tereny oraz intensywniej trzebić lasy ${ }^{99}$.
92 W parafii Żnin były to: Gogótkowo, Jaroszewo i Sarbinowo; w parafii Góra Arcybiskupia (oprócz miejscowości parafialnej): Białożewin, Januszkowo, Mościszewo (w 2. poł. XVI w. wieś pusta, włączona do folwarku w Wenecji), Murczyn, Podgórzyn i Wilczkowo; w parafii Gorzyce (oprócz miejscowości parafialnej): Dochanowo i Sulinowo; w parafii Wenecja (oprócz miejscowości parafialnej): Biskupin i Godawy. Ponadto do klucza żnińskiego należały wieś parafialna Juncewo, wieś parafialna Staboszewo, Pniewy w parafii Ostroszcze i Żędowo w parafii Chomętowo. Wizytacje dóbr arcybiskupstwa, s. 275-292, 296-308; J. Topolski, Rozwój latyfundium arcybiskupstwa gnieźnieńskiego od XVI do XVIII w., Poznań 1955, s. 55-59. Przejściowo w posiadaniu arcybiskupstwa znajdowała się także wieś Dobrylewo (parafia Góra Arcybiskupia), która przeszła w ręce arcybiskupa w 1523 r., jednak już w 1548 r. znów występuje w źródłach jako wieś szlachecka. L. Polaszewski, Własność feudalna, s. 41, 89-90, 185. Ryszewo od 1614 r. było własnością kapituły gnieźnieńskiej. Teki Dworzaczka: księgi grodzkie i ziemskie poznańskie, rezygnacje, XVII w., cz. 1, 6876 (nr 1409).

93 Były to: Bartodzieje w parafii Wagrowiec; Nowe w parafii Grylewo; Sarbka, Kamienica, Kaliszany i Oporzyn w parafii Żoń; Tarnowo, Kobylec, Krosno, Durowo, Rgielsko, Klasztorek i Bukowiec w parafii Tarnowo; Koninek, Bracholin w parafii Łekno; Turza i Mokronosy w parafii
Srebrna Góra; Panigrodz i Lęgniszewo w parafii Panigrodz; Bobrowniki w parafii Łęgowo. Ponadto do klasztoru w Wagrowcu należały cztery wsie z terenu powiatu gnieźnieńskiego: Łęgowo, Łaziska, Ochodza i Sienno. Wsie te w powiecie kcyńskim wspominają jeszcze rejestry poborowe z 1564 i 1565 r., jednak już w następnych są one wymieniane w powiecie gnieźnieńskim. ASK I 12, k. 584; ASK I 4, k. 234; ŻD, 12 , s. 161. Por. L. Polaszewski, Własność feudalna, s. 98-99.

94 LBG I, s. 182; E 40, k. 335, 336v; Wizytacje dóbr arcybiskupstwa, s. 539, 647; Rp1618, s. 233; S. Orsini-Rosenberg, Rozwój i geneza, tab. 1-2; L. Polaszewski, Własność feudalna, s. 92-93. Folwark Ujazd stanowił własność kościoła parafialnego w Kcyni. LBG I, s. 125. W XVI w. podlegał kapitule gnieźnieńskiej; był to jednak, jak się zdaje, stan przejściowy. L. Polaszewski, Własność feudalna, s. 91. Z 1651 r. pochodzi bowiem zapis, że pleban kcyński dzierżawi Krzepiszyn i Ujazd Stanisławowi Rakojeckiemu. Teki Dworzaczka, księgi grodzkie i ziemskie kcyńskie, 2071 (nr 129).

95 Zob. przyp. 23

96 LBG I, s. 109, 125, 132, 136-137, 144-145, 152.

97 Tamże, s. 169-170; E 40, k. 324; L. Polaszewski, Własność feudalna, s. $45,102$.

98 Zob. przyp. 45

99 K.J. Hładyłowicz, Zmiany krajobrazu, s. 84-86, 88, 134.

\section{IO4 Studia Geohistorica • Nr 03. 2015}




\section{Bibliografia}

\section{Źródła archiwalne i nieopublikowane}

Archiwum Archidiecezjalne w Gnieźnie, „Akta wizytacji archidiakonatu gnieźnieńskiego Wincentego de Seve 1608-1609", sygn. E 40.

Archiwum Archidiecezjalne w Poznaniu, „Wizytacja archidiakonatu poznańskiego 1628 1629”, sygn. AV 7.

\section{Źródła wydane drukiem}

Corpus iuris Polonici, vol. 3: Annos 1506-1522 continentis, wyd. O. Balzer, Cracoviae 1906.

Jana Easkiego [...] Liber beneficiorum archidiecezyi gnieźnieńskiej, wyd. J. Łukowski z uwagami J. Korytkowskiego, t. 1-2, Gniezno 1880-1881.

Kodeks dyplomatyczny Wielkopolski, t. 3, Poznań 1877.

Ksiegga uposażenia diecezji poznańskiej z roku 1510, wyd. J. Nowacki, Poznań 1950.

Lustracja województw wielkopolskich $i$ kujawskich 1564-1565, wyd. A. Tomczak, C. Ohryzko-Włodarska, J. Włodarczyk, cz. 1, Bydgoszcz 1961.

Lustracja województw wielkopolskich $i$ kujawskich 1659-1665, wyd. C. Ohryzko-Włodarska, cz. 1, Wrocław-Warszawa 1978.

Metryki chrztów z parafi smoguleckiej. Cz. 1 . Lata 1592-1618, wyd. M. Górny, „Genealogia”, 5, 1995, s. 105-140.

Metryki chrztów z parafi smoguleckiej. Cz. 2. Lata 1619-1652, wyd. M. Górny, „Genealogia”, 6, 1995, s. 89-132.

Polska XVI wieku pod względem geograficzno-statystycznym, t. 1: Wielkopolska, wyd. A. Pawiński, Warszawa 1883 (Źródła Dziejowe, 12).

Rejestr poborowy województwa kaliskiego 16181620, wyd. A.J. Parczewski, Warszawa 1879 (Analekta Wielkopolskie, 1).

Stownik historyczno-geograficzny województwa poznańskiego $w$ średniowieczu, cz. 1-5, Wrocław-Poznań 1982-2014.
Archiwum Główne Akt Dawnych w Warszawie, Archiwum Skarbu Koronnego, (rejestry poborowe), ASK I 4; ASK I 12; ASK I 13.

Teki Dworzaczka. Materiały historyczno-genealogiczne do dziejow szlachty wielkopolskiej XV-XX wieku, PAN i Biblioteka Kórnicka, Kórnik-Poznań 2004 (edycja elektroniczna: http://teki.bkpan.poznan.pl/index_glowna. html, dostęp: 11 lipca 2015).

Visitatio archidiaconatus Wladislaviensis [...] facta 1582 a., w: Monumenta Historica Dioeceseos Wladislaviensis, vol. 19, Wladislaviae 1900, s. 41-72.

Visitatio ecclesiarum dioecesis Wladilaviensis per [...] Mathiam Karski [...] de mandato [...] Stanislai Karnkowski ep. Wl. facta anno 1578 [...], w: Monumenta Historica Dioeceseos Wladislaviensis, vol. 17, Wladislaviae 1899, s. 5-45.

Visitatio ecclesiarum in archidiaconatu dioecesis Wladislaviensis consistentium per [...] Stanislaum Karnkowski episcopum Wladislaviensem et Pomeraniae [...] facta anno 1577 [...], w: Monumenta Historica Dioeceseos Wladislaviensis, vol. 17, Wladislaviae 1899, s. 45-135. Volumina constitutionum, t. 2: 1550-1609, vol. 2: 1587-1609, przyg. do druku S. Grodziski, Warszawa 2008.

Wizytacje dóbr arcybiskupstwa gnieźnieńskiego $i$ kapituty gnieźnieńskiej z XVI w., wyd. B. Ulanowski, Kraków 1920. 
Materiały kartograficzne

Atlas historyczny Polski. Rejestry poborowe województwa poznańskiego $w X V I w$, red. M. Słoń (http://atlasfontium.pl/, dostęp: 12 lipca 2015).

Karte von Ost-Preussen nebst preussisch Litthauen und West-Preussen nebst dem Netzdistrict aufgenommen unter Leitung des königl. Preuss. Staats Ministers Frey Herrn von Schroetter in den Jahren 1796 bis 1802, Berlin 1802 1812 , sek. $20+24$.

Mazowsze w drugiej potowie XVI wieku, oprac. W. Pałucki i in., Warszawa 1973 (Atlas historyczny Polski. Mapy szczegółowe XVI wieku, 7).

Województwo krakowskie w drugiej potowie XVI wieku, oprac. H. Rutkowski i in., Warszawa 2008 (Atlas historyczny Polski. Mapy szczegółowe XVI wieku, 1).

\section{Literatura przedmiotu}

Boras Z., W dobie szlacheckiej Rzeczpospolitej, w: Dzieje Wagrowca, red. E. Makowski, Poznań 1994, s. 57-90.

Borek A., Powiat kcyński $w$ drugiej potowie XVI w., w: Atlas historyczny Polski. Rejestry poborowe województwa kaliskiego $w X V I w$., red. M. Słoń (http://atlasfontium.pl/, dostęp: 11 lipca 2015).

Boroda K., Kmieć, tan czy profit? Co byto podstawa poboru tanowego w XV i XVI w.?, w: Cztowiek wobec miar $i$ czasu $w$ przesztości, red. P. Guzowski, M. Liedke, Kraków 2007, s. $152-167$.

Chłapowski K., Rejestry poborowe województwa kaliskiego z XVI wieku. Wstęp źródtoznawczy, w: Atlas historyczny Polski. Rejestry poborowe województwa kaliskiego $w X V I$ w. red. M. Słoń (http://atlasfontium.pl/, dostęp: 11 lipca 2015).

Chłapowski K., Starostowie w Wielkopolsce, na Kujawach i Mazowszu 1565-1696 (materiaty źródtowe), Warszawa 2007.

Chmielewski S., Od lokacji miasta do potowy XVII w. [1434-1654], w: Dzieje Chodzieży, red. S. Chmielewski, Chodzież 1998, s. 33-79.

Chodyła Z., Les moulins à vent en Pologne, w: I mulini nell'Europa medievale. Atti del Convegno di San Quirino d'Orcia 21-23 settem-
Województwo lubelskie $w$ drugiej potowie XVI wieku, oprac. S. Wojciechowski, Warszawa 1966 (Atlas historyczny Polski. Mapy szczegółowe XVI wieku, 3).

Województwo sandomierskie $w$ drugiej potowie $X V I$ wieku, oprac. W. Pałucki i in., Warszawa 1993 (Atlas historyczny Polski. Mapy szczegółowe XVI wieku, 2).

Województwo sieradzkie i województwo tęczyckie $w$ drugiej potowie XVI wieku, oprac. H. Rutkowski i in., Warszawa 1998 (Atlas historyczny Polski. Mapy szczegółowe XVI wieku, 5).

Ziemie polskie Korony w XVI w. Przestrzenna baza danych, Instytut Historii PAN im. Tadeusza Manteuffla (http://atlasfontium.pl/, dostęp: 12 lipca 2015).

bre 2000, a cura di P. Galetti, P. Racine, Bologna 2003, s. 175-202.

Dunin-Wąsowicz A., Pomiary gruntu $w$ Koronie w XVI-XVIII wieku: próba ustalenia wielkości ról chtopskich na ziemiach polskich, Warszawa 1994.

Filipczak-Kocur A., Skarbowość Rzeczypospolitej 1587-1648, Warszawa 2006.

Frančić M., Technika mtynów wodnych $w$ Polsce $w X V I$ i XVII $w$., ,Kwartalnik Historii Kultury Materialnej”, 2 (1-2), 1954, s. 79-103.

Gąsiorowski A., Powiat w Wielkopolsce w XIV$X V I$ wieku. $Z$ zagadnień zarzadu terytorialnego i podziatów Polski późnośredniowiecznej, Poznań 1965.

Gąsiorowski A., Starostowie wielkopolskich miast królewskich $w$ dobie jagiellońskiej, WarszawaPoznań 1981.

Gidaszewski T. i in., Transformations of the Natural Landscapes of the Middle Notec Region from the Tenth to the Sixteenth Century, $\mathrm{w}$ : Landscapes and Societies in Medieval Europe East of the Elbe. Interactions between Environmental Settings and Cultural Transformations, ed. S. Rossignol i in., Toronto 2013 (Papers in Mediaeval Studies, 23), s. 245-273.

Gieysztorowa I., Źródta i szacunki do osadnictwa $i$ demografii Polski XVI i XVII w., „Kwartal- 
nik Historii Kultury Materialnej”, 10 (3-4), 1962, s. 575-593.

Gieysztorowa I., Źródta pisane, w: Mazowsze $w$ drugiej potowie XVI wieku, cz. 2: Komentarz, indeksy, oprac. W. Pałucki i in., Warszawa 1973 (Atlas historyczny Polski. Mapy szczegółowe XVI wieku, 7), s. 17-22.

Górska K., Przyczynek do krytyki rejestrów poborowych z XVI wieku, „Studia Źródłoznawcze”, 1, 1957, s. 185-189.

Guldon Z., Uwagi w sprawie przydatności badawczej rejestrów poborowych z XVI w., „Zapiski Historyczne", 31 (1), 1966, s. 73-79.

Hładyłowicz K.J., Zmiany krajobrazu i rozwój osadnictwa $w$ Wielkopolsce od XIV do XIX wieku, Lwów 1932.

Janiszewska-Mincerowa B., Mincer F., W okresie staropolskim (XIV w.-1773), w: Dzieje Szubina, red. M. Biskup, Warszawa-Poznań 1974, s. 21-72.

Kamler M., Areat folwarku szlacheckiego $w$ Wielkopolsce Wschodniej 1580-1655, „Przegląd Historyczny”, 62 (2), 1971, s. 177-196.

Kamler M., Folwark szlachecki w Wielkopolsce w latach 1580-1655, Warszawa 1976.

Kamler M., Ean, hasło w: Encyklopedia historii gospodarczej Polski do 1945 r., red. A. Mączak, Warszawa 1981, t. 1, s. 446.

Kaniewska I., Latalski Janusz, hasło w: Polski Stownik Biograficzny, t. 16, Wrocław 1971, s. 563-564.

Karczewska J., Sredniowieczne miary powierzchni ziemi w Wielkopolsce i na Kujawach w świetle źródet sadowych, w: Cztowiek wobec miar $i$ czasu $w$ przesztości, red. P. Guzowski, M. Liedke, Kraków 2007, s. 143-151.

Karczewska J., Wtasność szlachecka na pograniczu wielkopolsko-kujawskim w pierwszej potowie XV wieku, Kraków 2010.

Kądziołka J., Żnin po lokacji (1263-1654), w: Żnin. 700 lat dziejów miasta, red. J. Topolski, W. Sobisiak, Bydgoszcz 1965, s. 49-75.

Klint P., Szlachecki obrót ziemią w powiecie kcyńskim w latach 1626-1655, Wrocław 2012.

Klonder A., Patuki w dobie wczesnonowożytnej, Gołańcz 2008 (Dzieje Pałuk, 3).

Konieczka-Śliwińska D., Dzieje Margonina $w$ dobie staropolskiej, w: Dzieje Margonina, red. K. Rzepa, Poznań 2002, s. 27-51.
Korytkowski J., Prataci i kanonicy katedry metropolitalnej gnieźnieńskiej od roku 1000 az do dni naszych, t. 1, Gniezno 1883.

Kowalska H., Rokossowski Jakub h. Glaubicz, hasło w: Polski Stownik Biograficzny, t. 31, Wrocław 1988-1989, s. 537.

Kozacki L., Charakterystyka środowiska przyrodniczego Patuk, w: Osadnictwo i architektura $w$ rejonie Łekna we wczesnym średniowieczu, red. A.M. Wyrwa, Poznań 1989 (Studia i Materiały do Dziejów Pałuk, 1), s. 23-42.

Kozierowski S., Szematyzm historyczny ustrojów parafialnych dzisiejszej archidiecezji poznańskiej, Poznań 1935.

Krzyś J., Cieślak C., Szkice z przesztości Barcina, Barcin 2009.

Kujawski W., Rozdrażewski (Rozrażewski) Jan h. Doliwa, hasło w: Polski Stownik Biograficzny, t. 32, Wrocław 1989-1991, s. 373-374.

Kulejewska-Topolska Z., Oznaczenia i klasyfkacje miast $w$ dawnej Polsce (XVI-XVIII w.), "Czasopismo Prawno-Historyczne”, 8 (2), 1956, s. 256-258.

Kurpisz L., Kronika kościotów chodzieskich, Chodzież 1933.

Leitgeber S., Potuliccy, Londyn 1990.

Leitgeber S., Smoguleccy herbu Grzymata. Dzieje rodziny od XVI do XVIII w., „Genealogia”, 6, 1995, s. 27-52.

Mincer F., Dzieje Kcyni do 1772 r., w: Dzieje Kcyni i okolic, red. W. Jastrzębski, Kcynia 1993, s. 27-71.

Moeglich M., Mtyny wagrowieckie w „czasach cysterskich”. Zarys problemu, w: Wangrovieciana. Studia et Fontes. Wagrowieckie studia muzealne, Wągrowiec 2013, s. 11-25.

Nowacki J., Dzieje archidiecezji poznańskiej, t. 2, Poznań 1964.

Nowicki R., Z przesztości Łabiszyna, Łabiszyn 1997.

Orsini-Rosenberg S., Rozwój i geneza folwarku pańszczyźnianego $w$ dobrach katedry gnieźnieńskiej wXVI w., Poznań 1925.

Polaszewski L., Wtasność feudalna w województwie kaliskim $w X V I$ w. Poznań 1976.

Rutkowski H., Granice pañstwowych jednostek terytorialnych, w: Województwo krakowskie $w$ drugiej potowie XVI wieku, cz. 2, oprac. H. Rutkowski i in., Warszawa 2008 (Atlas 
historyczny Polski. Mapy szczegółowe XVI wieku, 1), s. 27-35.

Samsonowicz H., Rzemiosto wiejskie w Polsce XIV-XVI w., Warszawa 1954.

Słoń M., Powiat gnieźnieński $w$ drugiej potowie $X V I w$., w: Atlas historyczny Polski. Rejestry poborowe województwa kaliskiego $w X V I w$. (http:// atlasfontium.pl/, dostęp: 12 lipca 2015).

Sochaniewicz K., Ślad, pótśledzie, kwarta $i$ kęs roli. (Ze studjów nad miarami $w$ Wielkopolsce w XVI i XVII w.), ,Roczniki Historyczne”, 5 (1), 1929, s. 90-102.

Szafran P., Osadnictwo historycznej Krajny w XVIXVIII w., Gdańsk 1961.

Święch J., Wiatraki. Mtynarstwo wietrzne na Kujawach, Włocławek 2001.

Topolski J., Gospodarstwo wiejkkie w dobrach arcybiskupstwa gnieźnieńskiego od XVI do XVII w., Poznań 1958.

Topolski J., Przyczyny powstania i rozwój folwarku pańszczyźnianego, w: Dzieje Wielkopolski, t. 1: Do roku 1793, red. J. Topolski, Poznań 1969, s. 445-459.

Topolski J., Rozwój latyfundium arcybiskupstwa gnieźnieńskiego od XVI do XVIII w., Poznań 1955.

Truchim S., Żnin za czasów królów elekcyjnych, w: Historia powiatu żninskiego, red. S. Truchim, Poznań 1928, s. 123-194.

Wędzki A., Okres staropolski, w: Gotańcz. Z dziejów miasta i regionu, red. A. Wędzki, Gołańcz 2001, s. 10-65.
Wędzki A., Patuki w średniowieczu, Żnin 1998 (Dzieje Pałuk, 2).

Wędzki A., Rozwój sieci miejskiej na Patukach w średniowieczu, w: tenże, Przechadzki po Wielkopolsce, Poznań 2007, s. 133-143.

Wiesiołowski J., Sieć miejska w Wielkopolsce $w$ XIII-XVI w. Przestrzeń i spoteczeństwo, „Kwartalnik Historii Kultury Materialnej”, 28 (3), 1980, s. 385-399.

Witkowski R., Czasy nowożytne (od początku $X V I$ w. do 1815 r.), w: Żnin. 750 lat dziejów miasta, t. 1, red. T. Janicki, Żnin 2013, s. 83-139.

Wyczański A., Studia nad folwarkiem szlacheckim $w$ Polsce $w$ latach 1500-1580, Warszawa 1960, s. 37-55.

Wyrwa A.M., Patuki-nazwa i terytorium w świetle źródet i literatury. Stan badań, w: Osadnictwo $i$ architektura $w$ rejonie Eekna we wczesnym średniowieczu, red. A.M. Wyrwa, Poznań 1989 (Studia i Materiały do Dziejów Pałuk, 1), s. 11-22.

Wyrwa A.M., Powstanie, organizacja i charakter cysterskiego ośrodka miejskiego w Wagrowcu, $\mathrm{w}$ : Klasztor $w$ mieście średniowiecznym i nowożytnym, red. M. Derwich, A. Pobóg-Lenartowicz, Wrocław-Opole 2000, s. 165-186.

Żmidziński F., Osadnictwo w starostwie ujsko-pilskim do roku 1772, „Rocznik Nadnotecki”, 1, 1966, s. 49-69.

\section{The District of Kcynia in the Second Half of the $16^{\text {th }}$ Century}

\section{Summary}

In the second half of the $16^{\text {th }}$ century, the district of Kcynia was administratively a part of the Kalisz voivodeship, which also comprised the districts of Kalisz, Pyzdry, Konin, Gniezno and Nakło. The district of Kcynia was situated in the northern part of the voivodeship, from the north bordering the district of Nakło and from the south the district of Gniezno. It constituted a part of the Kalisz voivodeship since 1768 , when three northern districts were separated from that voivodeship, namely of Gniezno, Kcynia and Nakło - thus establishing the Gniezno voivodeship. The source basis of the reconstruction of settlement, together with state and church administrative divisions in 1600 are the so-called tax registers, which were the lists of incomes from the extraordinary tax temporarily passed by the Seym of the Republic 
of Poland for military purposes. In the second half of the $16^{\text {th }} \mathrm{c}$. it acquired a common character, including all categories of the population and industrial facilities functioning in rural and urban areas. The censuses were performed according to the administrative division into voivodeships and districts as well as parishes inside them. For the second half of the $16^{\text {th }} \mathrm{c}$. eleven tax registers of the district of Kcynia have been preserved from the years 1564-1591, at present kept in the Central Archives of Historical Records in Warsaw. Data from the registers are supplemented with the information from other sources, first of all ecclesiastical ones.

The settlement network of the district of Kcynia was mostly shaped already in the period of the Middle Ages $\left(13^{\text {th }}-15^{\text {th }}\right.$ centuries). The number of new settlements in the $16^{\text {th }} \mathrm{c}$., especially in the second half, was already small. In the period under discussion the district of Kcynia comprised $2400 \mathrm{~km}^{2}$ and the number of identified settlement sites can be determined at 317 , which means that one settlement included approximately $7.5 \mathrm{~km}^{2}$. In that time there were 13 towns in the area of the district, the biggest being Żnin, which belonged to the archbishop of Gniezno and which had 2500 inhabitants. The population of the district capital Kcynia, the seat of the starost (overseer of the Crown lands), can be estimated at about 1000 persons. The district of Kcynia mostly included small rural settlements with the area not exceeding 10 lans (a unit of field measurement) of arable land plus the manor lands. The area of the arable land (except the manor lands) in the district of Kcynia was at that time about $340 \mathrm{~km}^{2}$, which was a little more than $14 \%$ of the whole area of the district. The total size of the usable area can be estimated at only $30 \%$ of the whole district area, while the rest included forests and waste land.

The gentry property clearly predominated, constituting about $79 \%$ of the whole estate, while $18 \%$ was church property and only $2 \%$ of the lands belonged to the kind, while $1 \%$ was a mixed property.

It can be stated on the basis of the sources that in the district of Kcynia at that time nearly 40 watermills and more than 50 windmills functioned and they were concentrated in the central part of the region with the least forestation.

The area of the district of Kcynia in the period under discussion was divided between three dioceses, namely of Gniezno, Poznań and Wrocław. Most of the area belonged to the archdeanery of Gniezno of the Gniezno archdiocese and within it, to three deaneries: of Łekno, Żnin and Gniezno-St. Peter. Forty one parishes had their seats in the area of the district.

Słowa kluczowe: powiat kcyński, województwo kaliskie, rejestr poborowy, Wielkopolska w XVI w., osadnictwo, Atlas historyczny Polski

Keywords: Kcynia district, Kalisz Voivodeship, tax register, Greater Poland in the $16^{\text {th }}$ century, settlement, Historical Atlas of Poland

mgr Marta Piber-Zbieranowska - pracownik Instytutu Historii PAN w Warszawie, w latach 1998-2012 w Zakładzie Atlasu Historycznego, od 2012 r. w Zespole Stownika Historyczno-Geograficznego Mazowsza w Średniowieczu (e-mail: mpiber@ihpan.edu.pl) 